\title{
Recent Developments of Effective Catalysts for Hydrogen Storage Technology Using N-Ethylcarbazole
}

\author{
Liu Zhou ${ }^{1}$, Lin Sun ${ }^{1}$, Lixin Xu ${ }^{1}$, Chao Wan ${ }^{1,2,3,4, * \mathbb{D}}$, Yue An ${ }^{4}$ and Mingfu Ye ${ }^{1,2, *}$ \\ 1 School of Chemistry and Chemical Engineering, Anhui Province Key Laboratory of Coal Clean Conversion \\ and High Valued Utilization, Anhui University of Technology, Ma'anshan 243002, China; \\ iLiu97@hotmail.com (L.Z.); sunlinone@outlook.com (L.S.); 1xxu@hotmail.com (L.X.) \\ 2 Ahut Chemical Science \& Technology Co., Ltd., Ma'anshan 243002, China \\ 3 Anhui Haide Chemical Technology Co., Ltd., Ma'anshan 243002, China \\ 4 Zhejiang Provincial Key Laboratory of Advanced Chemical Engineering Manufacture Technology, \\ College of Chemical and Biological Engineering, Zhejiang University, 38 Zheda Road, Hangzhou 310027, \\ China; zju.anyue@hotmail.com \\ * Correspondence: wanchao1219@hotmail.com (C.W.); yehmf@iccas.ac.cn (M.Y.); Tel.: +86-555-231-1807 (C.W.)
}

Received: 29 April 2020; Accepted: 6 June 2020; Published: 10 June 2020

\begin{abstract}
Hydrogen energy is considered to be a desired energy storage carrier because of its high-energy density, extensive sources, and is environmentally friendly. The development of hydrogen storage material, especially liquid organic hydrogen carrier (LOHC), has drawn intensive attention to address the problem of hydrogen utilization. Hydrogen carrier is a material that can reversibly absorb and release hydrogen using catalysts at elevated temperature, in which LOHC mainly relies on the covalent bonding of hydrogen during storage to facilitate long-distance transportation and treatment. In this review, the chemical properties and state-of-the-art of LOHCs were investigated and discussed. It reviews the latest research progress with regard to liquid organic hydrogen storage materials, namely N-ethylcarbazole, and the recent progress in the preparation of efficient catalysts for $\mathrm{N}$-ethylcarbazole dehydrogenation by using metal multiphase catalysts supported by carbon-nitrogen materials is expounded. Several approaches have been considered to obtain efficient catalysts such as increasing the surface area of the support, optimizing particle size, and enhancing the porous structure of the support. This review provides a new direction for the research of hydrogen storage materials and considerations for follow-up research.
\end{abstract}

Keywords: hydrogen storage; liquid organic hydrogen carrier; hydrogen economic; N-ethylcarbazole

\section{Introduction}

Hydrogen, as a green and sustainable energy carrier, has been generally recognized as the most promising alternative to replace traditional fossil fuels due to its abundant reserves, extensive sources, and high energy density [1-7]. However, hydrogen utilization faces several problems such as hydrogen generation, storage and transportation, and hydrogen application [8-14], in which hydrogen storage and transportation plays an important role. Thus, in order to solve the above-mentioned problems, seeking a kind of hydrogen storage approach is of importance. The means of hydrogen storage are pressurized gaseous hydrogen storage [15], cryogenic liquefaction hydrogen storage [16], metal alloy hydrogen storage [17], liquid organic hydrogen storage [18-23], etc. Scheme 1 [24] demonstrates that molecules rich in hydrogen can be stored for long periods of time without loss of energy, and can be transported over long distances using existing energy transport logistics such as pipelines, ships, and trucks [25-30]. Pressurized gas hydrogen has storage maneuverability, but poor hydrogen 
storage performance, high energy consumption, and high transportation cost. Low temperature liquid hydrogen storage has high energy consumption and the high requirements of equipment. Cryogenic liquefaction hydrogen storage has a high cost and metal alloy is difficult to transport and the hydrides of these materials are too stable. Compared with the above hydrogen storage methods, LOHCs have many obvious advantages such as a large amount of organic liquid hydrogen storage, high volume density, and multiple recycling [31-37].

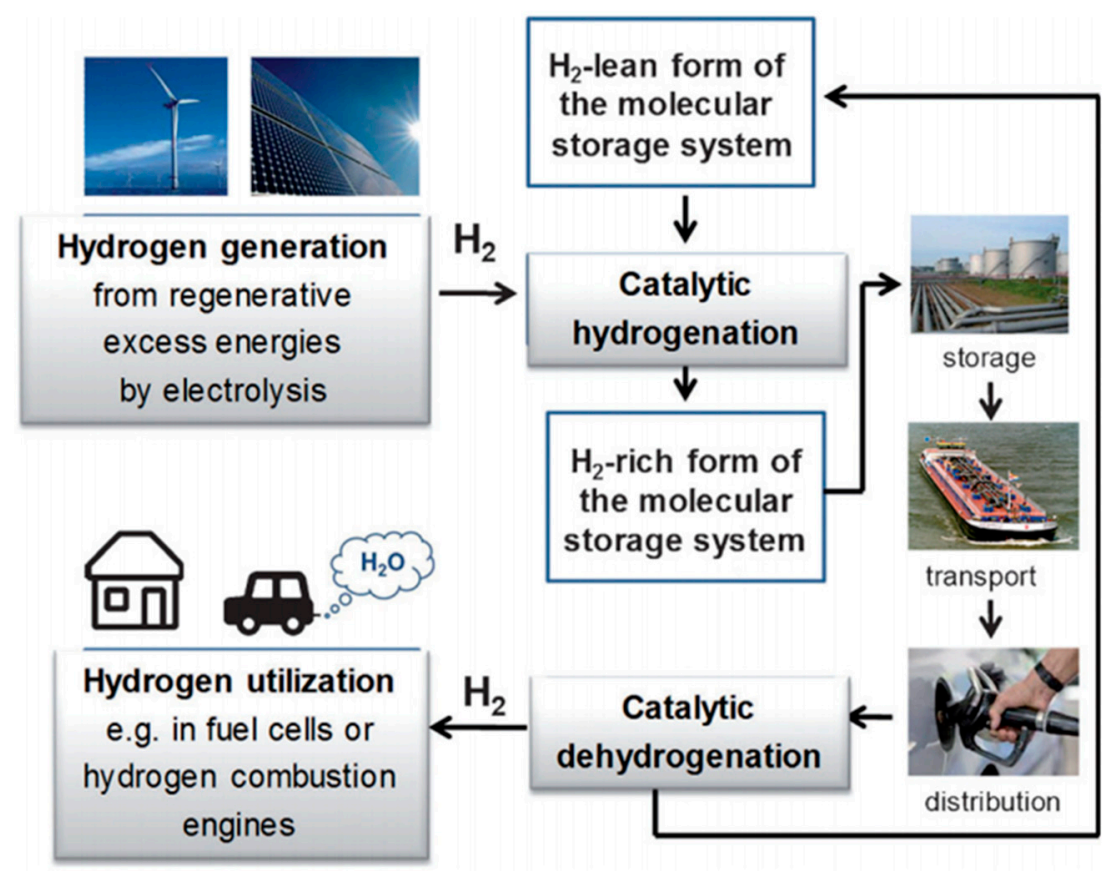

Scheme 1. Schematic representation of $\mathrm{H}_{2}$-based concepts of chemical energy storage and transport using existing distribution infrastructure; copyright (2014), ChemPubSoc Europe.

LOHC is a new hydrogen storage technology developed in the 1980s, whose principle is realized by a pair of reversible reactions of unsaturated liquid organic matter and hydrogen, namely hydrogenation reaction [38]. Alkenes [39-41], alkynes [42-44], aromatic hydrocarbons [45,46], N-propylcarbazole [47], and other unsaturated organics [48-50] can be used as hydrogen storage materials. However, considering the energy consumption, hydrogen storage, and physical properties of the hydrogen storage process, aromatic hydrocarbons, especially monocyclic aromatic hydrocarbons, are the optimum [51-54]. The LOHCs were first proposed by Sultan [38] in 1975, mainly using liquid aromatic compounds as benzene, toluene, and naphthalene rings. However, at present, the dehydrogenation temperature of these is much higher than the operating temperature of fuel cells [55-60]. In addition, the catalytic dehydrogenation process has side reactions, resulting in the impurity of hydrogen, and the dehydrogenation kinetic speed cannot meet the demand [60-64]. To address the above problems, Pez [65] was the first to design and predict some liquid organic molecules from theoretical calculation. It has been shown that the introduction of heterocyclic nitrogen into hydrogenated polyaromatic compounds can effectively reduce the heat of the dehydrogenation reaction. N-ethylcarbazole is the first organic liquid hydrogen storage material that can be completely hydrogenated/dehydrogenated at dehydrogenation temperature below $200{ }^{\circ} \mathrm{C}$.

Since the hydrogenation reaction of organic liquid is a thermodynamic exothermic process, it is relatively easy to completely catalyze the hydrogenation reaction, while the dehydrogenation reaction is a strongly endothermic and highly reversible reaction [66-71]. Therefore, it is a key goal to find a suitable dehydrogenation catalyst for the application of liquid hydrogen storage technology [72-74]. In this paper, the latest research progress of liquid organic hydrogen storage material N-ethylcarbazole was reviewed, as was the research progress of metal heterogeneous catalysts supported on carbonitride 
materials for preparing highly efficient $\mathrm{N}$-ethylcarbazole dehydrogenation catalysts. The development of catalysts and reaction models for the dehydrogenation of $\mathrm{N}$-ethylcarbazole are discussed, with the hope to provide some inspiration for future research in this field.

\section{Common Ways of Hydrogen Storage}

Hydrogen storage technology refers to the hydrogen in a stable form of energy that is stored for easy use. The key goal of hydrogen storage technology is how to improve the energy density of hydrogen. Hydrogen storage technology is often measured by the mass density of hydrogen, that is, the ratio of the mass of hydrogen released to the total mass. At present, there are many hydrogen storage technologies reported in the literature such as pressurized gaseous hydrogen storage, low temperature liquefaction hydrogen storage, metal alloy hydrogen storage, carbon material hydrogen storage, glass microsphere hydrogen storage, and organic liquid hydrogen storage, etc.

\subsection{Pressurized Gaseous Hydrogen Storage}

Pressurized gaseous hydrogen storage technology [15], which compresses hydrogen under high pressure and stores it in the form of high-density gas, is the most direct and common method for hydrogen storage because of its low cost, low energy consumption, easy dehydrogenation, and wide working conditions. The advantage of gaseous hydrogen storage is that it can be charged and discharged quickly, the cost is low, and the hydrogen storage capacity is small. The hydrogen storage capacity of a standard high pressure cylinder filled with $15 \mathrm{MPa}$ hydrogen is only $1.0 \%$. However, the hydrogen storage density is greatly affected by the pressure, and the pressure is limited by the material of the tank, in addition, in the process of hydrogen compression, a large amount of compression work is needed to be consumed. Therefore, at present, the research focus is on the improvement of tank material.

\subsection{Low Temperature Liquefaction Hydrogen Storage}

The technology of low-temperature liquefaction hydrogen storage [75] makes use of the characteristics of hydrogen liquefaction under high pressure and low temperature, and the volume density of hydrogen is 845 times of that of gaseous hydrogen. However, to ensure low-temperature and high-pressure conditions, not only do the requirements for the material of the storage tank need to be satisfied, but also the need for supporting strict insulation solutions and cooling equipment. Therefore, the storage tank of low-temperature liquefied hydrogen storage is generally small, and the following problems exist in the mass density of hydrogen: in order to improve the insulation efficiency, an insulation layer or insulation preparation must be added, and how to overcome the contradiction between the insulation and hydrogen storage density.

\subsection{Carbon Hydrogen Storage}

Hydrogen storage by carbonaceous materials $[76,77]$ is a hydrogen storage technology developed in recent years according to the theory of adsorption. It refers to materials such as carbon materials that absorb and store hydrogen such as carbon nanotubes, graphite nanofibers, etc., and have excellent hydrogen absorption and desorption properties. However, researchers should also carry out further research in the following aspects: (1) strengthen basic research, develop high-performance composite carbon hydrogen storage materials, enhance comprehensive properties, for a more in-depth theoretical analysis; and (2) the actual hydrogen storage process should be reasonably simplified and the research on the hydrogen storage mechanism should be strengthened. Although the research on the hydrogen storage of carbon nanomaterials has made some progress, the technology of the mass production of carbon nanomaterials is not mature and the cost is too high. Therefore, the hydrogen storage mechanism, composite doping modification, and structure control should be further studied in the future. 


\subsection{Metal Alloy Hydrogen Storage}

Hydrogen storage alloys [78] are intermetallic compounds that can reversibly absorb, store, and release hydrogen in large quantities at a given temperature and pressure. Hydrogen storage alloys use metals or alloys to react with hydrogen to form hydride, which are then used to store hydrogen, and hydrogen is released when the hydride is heated. It is safer to store hydrogen in hydride than in gaseous, high pressure, or liquefied hydrogen storage. Solid hydrogen storage based on hydrides is considered as one of the most promising hydrogen storage methods because of its advantages such as reversible circulation and mature technology. Metal based hydrogen storage alloys are mainly divided into magnesium, rare earth, and titanium hydride. To be commercialized, the hydrogen absorption capacity per unit mass and volume must be increased, and the decomposition temperature and pressure must be reduced to reduce the amount of energy required to release hydrogen. Hydrogen storage in metal alloys is characterized by the atomic state of hydrogen stored in the alloy, where the security is higher. However, the hydrides of these materials are too stable and the heat exchange is difficult. Thus, the hydrogenation/dehydrogenation can only be carried out at higher temperatures.

\subsection{Glass Microspheres for Hydrogen Storage}

Hollow glass beads are impermeable at low temperatures or room temperature, but porous at high temperatures. The principle of hydrogen storage is that under a certain temperature and pressure, hydrogen can enter the glass body. When the temperature drops close to room temperature, the permeability of the glass body disappears, and hydrogen remains in the glass microspheres. Its hydrogen storage density is as high as $1.5 \%$, which is a promising hydrogen storage technology, especially for hydrogen-powered vehicle systems [79]. The disadvantage is that, on one hand, the difficulty lies in the preparation of hollow microspheres with high strength, and on the other hand, the glass microspheres have a low hydrogen release rate because of their low thermal conductivity.

\subsection{Complex Hydrogen Storage}

The complex hydrogen storage materials [80] are composed of alkali metals ( $\mathrm{Li}, \mathrm{Na}, \mathrm{K})$ or alkaline earth metals $(\mathrm{Mg}, \mathrm{Ca})$ and major group III elements $(\mathrm{B}, \mathrm{Al})$. At present, the developed high capacity complex hydrogen storage materials mainly include metal aluminum compound hydride, metal borohydride, and metal nitride hydride, etc. The theoretical hydrogen storage capacity of these materials is high, for example, the theoretical hydrogen storage capacity of $\mathrm{NaBH}_{4}, \mathrm{Mg}\left(\mathrm{BH}_{4}\right)_{2}$, and $\mathrm{LiBH}_{4}$ are $10.8 \%, 14.9 \%$, and $18 \%$, respectively; however, hydrogen storage of these kinds of materials is not reversible and is often accompanied by side reactions. Currently, as a promising hydrogen storage material, researchers are still trying to explore ways to improve its dehydrogenation performance at low temperature. At the same time, the recovery, recycling, and reuse of this kind of material are also being studied in depth.

\subsection{Organic Liquid Hydrogen Storage}

Organic liquid hydride hydrogen storage technology [81-83] (Table 1) realizes hydrogenation and dehydrogenation by means of a pair of reversible reactions of hydrogen storage agents such as certain olefins, alkynes, or aromatic hydrocarbons and hydrogen. Organic liquid hydride hydrogen storage has the following characteristics. (1) The catalytic process is reversible, the reactants and products can be recycled, and the hydrogen storage density is high (both are above the department of energy (DOE) requirements). (2) Hydrogen carrier storage, transportation, and maintenance are safe and convenient, and the storage equipment is simple, especially suitable for long-distance transmission of hydrogen energy. For regions with relatively unbalanced supply and demand between western and eastern regions of China, long-distance transportation by pipeline in the form of an organic liquid may solve the problem of uneven distribution of energy in regions. (3) Taking the closed cycle system composed of benzene hydrogen storage as an example, if the heat released during the benzene 
hydrogenation reaction can be fully recovered, the efficiency of the entire cycle process can reach 98\% [84]. (4) In principle, it can be stored and transported at room temperature and pressure like gasoline, which has the advantage of directly using the existing gasoline transportation method and the structure of the gas station.

Table 1. Hydrogen storage capacity of different hydrogen storage technologies.

\begin{tabular}{ccc}
\hline Hydrogen Storage Mode & Hydrogen Storage Capacity/\% & Ref. \\
\hline Pressurized gaseous hydrogen storage & $1-3$ & {$[15]$} \\
Low temperature liquefaction hydrogen storage & $>10$ & {$[75]$} \\
Carbon hydrogen storage & $3-10$ & {$[76]$} \\
Metal alloy hydrogen storage & $1-8$ & {$[78]$} \\
Glass microspheres for hydrogen storage & $>15$ & {$[79]$} \\
Complex hydrogen storage & $5.5-18.5$ & {$[80]$} \\
Organic liquid hydrogen storage & $5-10$ & {$[83]$} \\
\hline
\end{tabular}

\section{The Development of Hydrogen Storage Materials}

The early research on chemical hydrogen storage of liquid organic hydrides has mainly focused on cycloalkanes by catalytic dehydrogenation of cycloalkanes and corresponding aromatics [85]. However, due to the high enthalpy of dehydrogenation, there is still a lot of heat in the hydrogen release process [76]. In recent years, experimental and theoretical studies have shown that the addition of nitrogen atoms to the cyclic system can reduce the endothermic property of the reaction [86], thus promoting the dehydrogenation process, making nitrogen substituted for heterocyclic compounds a potential organic hydrogen storage platform. Further density functional theory (DFT) calculations by Grabtree, Eisenstein et al. [87] showed that the introduction of $\mathrm{N}$ atoms into a six-membered ring, especially at the 1,3-position, greatly enhanced the release of hydrogen. Zhu et al. [88] analyzed the advantages and disadvantages of various hydrogen storage materials in detail in Table 2, and found that most cyclic organic chemical hydrides were light, inexpensive, and relatively low in oxidation, but had high hydrogen density. In particular, adding impurities such as $\mathrm{N}$ and $\mathrm{B}$ to the organic cycle greatly reduced their enthalpy of dehydrogenation. 
Table 2. Comparative physicochemical data for various potential liquid chemical hydrides; copyright (2012), RSC publishing.

\begin{tabular}{|c|c|c|c|c|c|c|c|}
\hline \multirow{2}{*}{ Entry } & & \multirow{2}{*}{ Storage Media } & \multirow{2}{*}{ Density } & \multirow{2}{*}{ Calculated (and Experimental) } & \multicolumn{2}{|c|}{ Hydrogen Content } & \multirow{2}{*}{ Ref. } \\
\hline & & & & & $w t \%$ & gL & \\
\hline \multicolumn{8}{|c|}{ Cycloalkanes } \\
\hline & 1 & Cyclohexane & 0.779 & $15.6(16.42)$ & 7.2 & 56 & [89] \\
\hline & 2 & Methylcyclohexane & 0.77 & 16.3 & 6.2 & 47.4 & {$[90]$} \\
\hline & 3 & Decalin & 0.896 & (cis-)15.1(15.29)(trans-)15.8(15.91) & 7.3 & 65.3 & {$[91]$} \\
\hline & 4 & Bicyclohexyl & 0.883 & 16 & 7.3 & 64.2 & [92] \\
\hline \multicolumn{8}{|c|}{ N-substituted heterocycles } \\
\hline & 5 & Dodecahydrocarbazole & 1.298 & 12.2 & 6.7 & 87 & [93] \\
\hline & 6 & Dodecahydro-N-ethylcarbazole & 0.931 & $12.1(12.4) \mathrm{a}$ & 5.8 & 54 & {$[94]$} \\
\hline & 7 & Indoline & 1.063 & 13.3 & 1.7 & 18.1 & [95] \\
\hline & 8 & 4-Aminopiperidine & 0.945 & - & 6 & 57 & [96] \\
\hline & 9 & Piperidine-4-carboxamide & - & - & 4.7 & - & [96] \\
\hline & 10 & Perhydro-4,7-phenanthroline & 0.958 & - & 7.2 & 69 & [94] \\
\hline & 11 & 2-Methyl-1,2,3,4-tetrahydroquinoline & - & - & 2.7 & - & [97] \\
\hline & 12 & 2,6-Dimethyldecahydro- 1,5 naphthyridine & - & - & 6 & - & [98] \\
\hline \multicolumn{8}{|c|}{ 1,2-BN-heterocycles } \\
\hline & 13 & 1,2-BN-cyclohexane & 1.011 & - & 4.7 & - & [99] \\
\hline & 14 & 3-Methyl-1,2-BN-cyclopentane & 0.894 & - & 4.7 & 48 & [99] \\
\hline \multicolumn{8}{|c|}{ Other organic chemical hydrides } \\
\hline & 15 & Methanol & 0.791 & - & $12.6(12.1)$ & 98.8 & [100] \\
\hline & 16 & Formic acid & 1.22 & - & 4.4 & 53 & [101] \\
\hline \multicolumn{8}{|c|}{ Inorganic chemical hydrides } \\
\hline & 17 & Ammonia borane & 0.78 & - & 19.6(9.0) & 153 & [101] \\
\hline
\end{tabular}




\section{Interconversion of $\mathrm{H}_{2} / \mathrm{N}$-Ethylcarbazole and Dodecahydro-N-Ethylcarbazole for Hydrogen Storage}

\subsection{Hydrogenation of N-Ethylcarbazole}

Since Sultan et al. [38] published their groundbreaking study in 1975, there have been many reports on LOHCs, with the most prominent being N-ethylcarbazole. Eblagon et al. [102] used Ru catalysts with different supports to study the hydrogenation of ethylcarbazole, and explored the interaction mechanism between ethylcarbazole molecules and the active sites on the metal surface. Eblagon et al. [103] compared the catalytic hydrogenation performance of ethyl carbazole with different supported catalysts of $\mathrm{Ru}, \mathrm{Rh}$, and $\mathrm{Pd}$, and the hydrogenation rate of each reaction, and established a reaction process model, and further studied the theoretical catalytic hydrogenation mechanism. The results show that catalytic hydrogenation is a gradual process; that $5 \% \mathrm{Ru} / \mathrm{Al}_{2} \mathrm{O}_{3}$ has the best catalytic performance; that the hydrogen storage density can reach $5.7 \mathrm{wt} \%$; and the conversion and selectivity of ethylcarbazole depends on the metal type and loading type of the catalyst. Due to the spatial constraints of the surface position, ethylcarbazole is partially hydrogenated to form an intermediate product. It is difficult to further hydrogenate to generate dodecylhydroethylcarbazole. The hydrogenation reaction of the ethylcarbazole system in the molten state was investigated in this document, and it was found that the activation energy measured in the hydrogenation reaction in the molten state was lower than that reported in previous solvents. However, a combination of experimental and theoretical studies showed that the Ru catalyst has a low selectivity to the desired product and accumulated a kinetically stable intermediate, octahydro-N-ethylcarbazole, which is further hydrogenated due to weak adsorption and poor surface diffusion of the intermediate [104-106].Yang et al. [107] studied the cyclic hydrogenation of ethylcarbazole and the stepwise dehydrogenation of dodecylethylcarbazole controlled by temperature. The experiment found that when using $5 \mathrm{wt} \% \mathrm{Ru} / \mathrm{Al}_{2} \mathrm{O}_{3}$ as the catalyst at $180{ }^{\circ} \mathrm{C}$ and $80 \mathrm{~atm}$, the mass hydrogen storage density of ethylcarbazole reached $5.79 \mathrm{wt} \%$; the removal of dodecylhydroethylcarbazole was catalyzed by $5 \mathrm{wt} \% \mathrm{Pd} / \mathrm{Al}_{2} \mathrm{O}_{3}$. The hydrogen reaction went through three processes including dodecylhydroethylcarbazole-octahydroethylcarbazole, octahydroethylcarbazole-tetrahydroethylcarbazole, and tetrahydroethylcarbazole-ethylcarbazole. After the hydrogen storage system underwent ten cycles of addition and dehydrogenation, the hydrogen storage capacity was only slightly reduced.

Wan et al. $[108,109]$ carried out a hydrogen absorption experiment of ethylcarbazole using the device as shown in Figure 1, and made a detailed study on the kinetics of the N-ethylcarbazole hydrogenation reaction and the main factors affecting the dehydrogenation performance of fully hydrogenated $\mathrm{N}$-ethylcarbazole such as the amount of catalyst and reaction temperature. The results showed that the optimal reaction conditions were $6.0 \mathrm{MPa}, 413 \mathrm{~K}, 1.0 \mathrm{~g} \mathrm{Ru} / \mathrm{g}-\mathrm{Al}_{2} \mathrm{O}_{3}, 600 \mathrm{rpm}$, and the apparent activation energy was $27.01 \mathrm{KJ} \mathrm{mol}^{-1}$.

$\mathrm{Yu}$ et al. [110] studied the bimetallic $\mathrm{Ru}-\mathrm{Ni} / \mathrm{TiO}_{2}$ for N-ethylcarbazole (NEC) hydrogenation in 2019, and studied the hydrogenation rates of $\mathrm{P} 25-\mathrm{TiO}_{2}$, Anatase- $-\mathrm{TiO}_{2}$, and Rutile- $\mathrm{TiO}_{2}$. As shown in Figure $2 \mathrm{a}$, for $\mathrm{Ru} / \mathrm{TiO}_{2}$, the hydrogenation rate decreased in the order of $\mathrm{P} 25>$ rutile $>$ anatase. For the bimetallic $\mathrm{Ru}-\mathrm{Ni} / \mathrm{TiO}_{2}$, the order was P25 $>$ anatase $>$ rutile. From Figure $2 b$, it can be clearly seen that the addition of $\mathrm{Ni}$ is harmful to $\mathrm{Ru} / \mathrm{rutile}$, but beneficial to $\mathrm{Ru} /$ anatase, especially for P25 with a higher selectivity and hydrogenation rate. Finally, the correct choice of catalyst carrier plays a significant role in the development of NEC high-performance hydrogenation catalysts.

In 2019, Wu et al. [18,19] found that $\mathrm{YH}_{3}$ could significantly improve the hydrogen absorption efficiency of $\mathrm{Ni} / \mathrm{Al}_{2} \mathrm{O}_{3}$ for NEC, which was much higher than that of all Ni-based NEC catalysts previously reported. It can be seen from Figure 3a that the hydrogen absorption efficiency of $\mathrm{Ni}_{10 \mathrm{~nm}} / \mathrm{Al}_{2} \mathrm{O}_{3}-\mathrm{YH}_{3}$ for NEC was obviously lower than that of $\mathrm{Ni}_{500 \mathrm{~nm}} / \mathrm{Al}_{2} \mathrm{O}_{3}-\mathrm{YH}_{3}$. This is because when the size of the Ni particles is equal to $\mathrm{YH}_{3}$, the $\mathrm{Ni}-\mathrm{YH}_{3}$ interface is more likely to be formed during the premixing process. When Ni particles are smaller than $\mathrm{Al}_{2} \mathrm{O}_{3}$ and uniformly loaded on $\mathrm{Al}_{2} \mathrm{O}_{3}$, larger $\mathrm{YH}_{3}$ particles are surrounded by smaller $\mathrm{Ni} / \mathrm{Al}_{2} \mathrm{O}_{3}$ particles. However, the usability of the yh3-ni interface is significantly reduced because Ni particles are smaller than $\mathrm{Al} 2 \mathrm{O} 3$. This difference 
can be seen in the transmission electron microscope (TEM) image and schematic diagram in Figure $3 b$,c. For $\mathrm{Ni} / \mathrm{Al}_{2} \mathrm{O}_{3}$ with larger Ni particles, $\mathrm{Al}_{2} \mathrm{O}_{3}$ particles are no longer used as the carrier of larger $\mathrm{Ni}$ particles, but the aggregation of $\mathrm{Ni}$ and $\mathrm{YH}_{3}$ particles can be effectively prevented and the stable catalytic performance can be maintained during the reaction process.

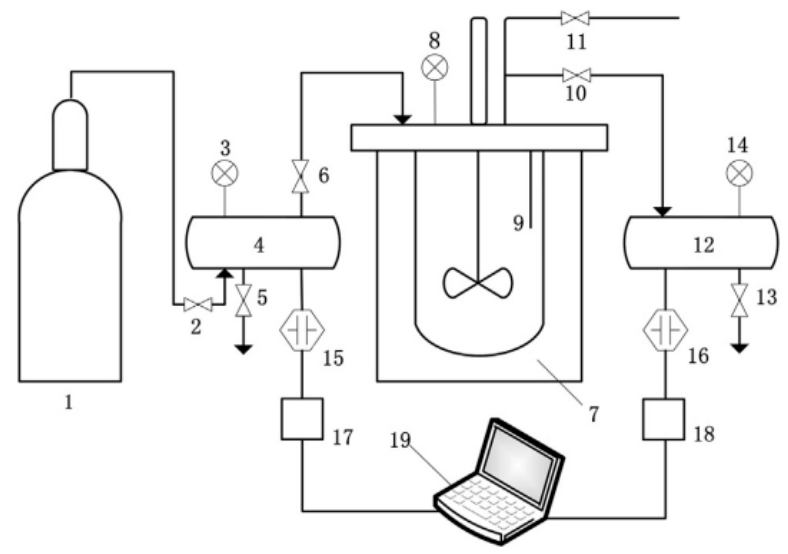

Figure 1. Scheme diagram of the experimental system with (1) hydrogen source; (2), (6), (10) connection valve; (3), (8), (14) pressure gauge; (4), (12) hydrogen reservoir; (5), (11), (13) exhaust pipe valve; (7) stainless steel autoclave; (9) thermocouple temperature control; (15), (16) pressure; copyright (2012), Int. J. Hydrogen Energy.
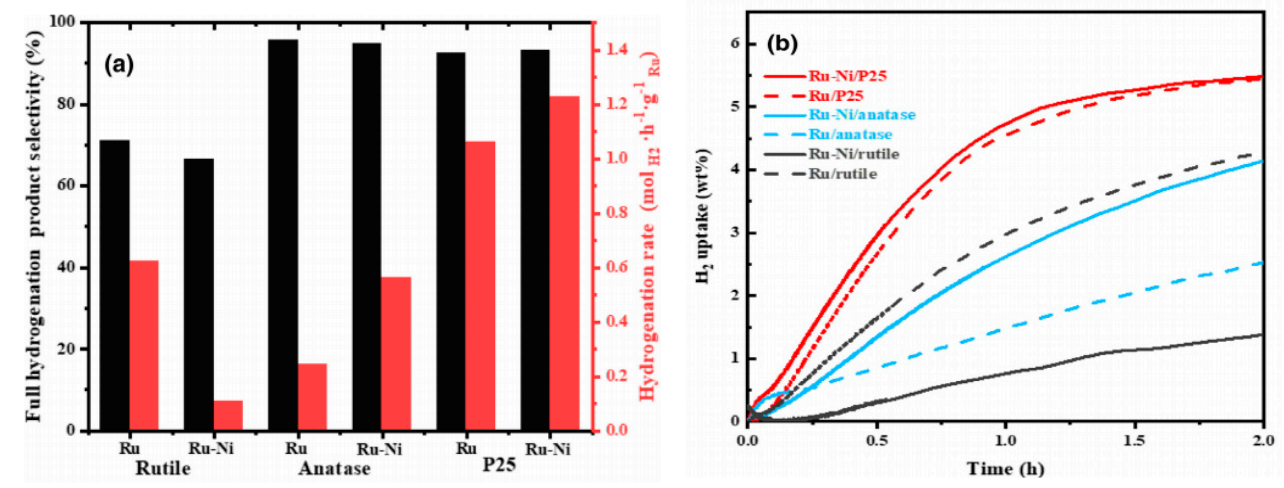

Figure 2. Catalytic performances of as-prepared catalysts. (a) The left axis shows selectivity toward the full hydrogenation product 12H-NEC (after reacting $24 \mathrm{~h}$ ); the right axis shows the hydrogenation rate. Reaction condition: $150{ }^{\circ} \mathrm{C}, 70$ bar H$_{2}, 2.5 \mathrm{~g} \mathrm{NEC}, 0.125 \mathrm{~g}$ catalyst, $24 \mathrm{~h}$, stirring at $200 \mathrm{rpm}$. (b) The first $2 \mathrm{~h}$ of the primitive $\mathrm{H}_{2}$ uptake curve; copyright (2020), Journal of Energy.
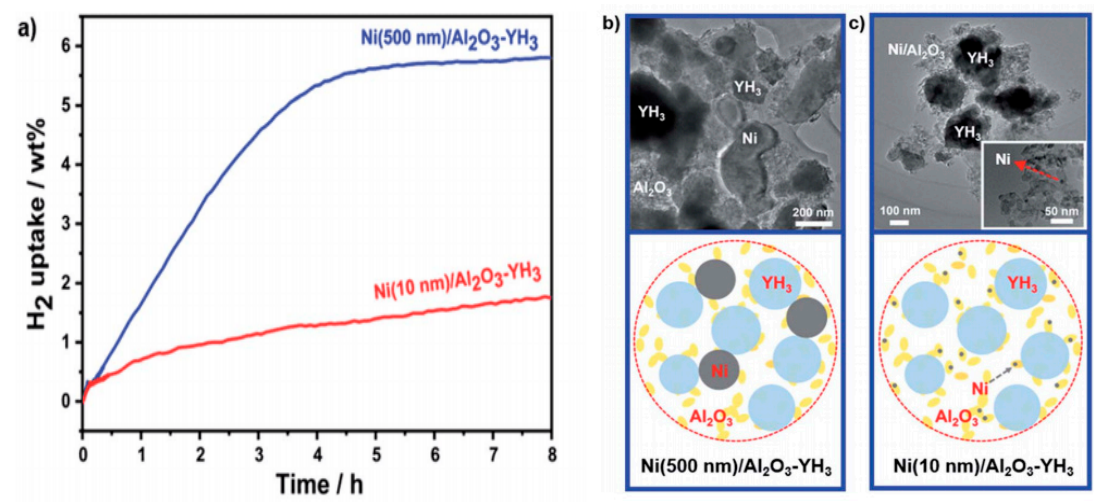

Figure 3. (a) Hydrogen absorption kinetics of NEC on two different $\mathrm{Ni} / \mathrm{Al}_{2} \mathrm{O}_{3}-\mathrm{YH}_{3}$ catalysts $\left(150{ }^{\circ} \mathrm{C}\right.$, $3 \mathrm{MPa} \mathrm{H}_{2}, 1.00 \mathrm{~g} \mathrm{NEC}, 25 \mathrm{mg} \mathrm{Ni} / \mathrm{Al}_{2} \mathrm{O}_{3}$, and $100 \mathrm{mg} \mathrm{YH}$ ). (b,c) TEM images and schematic illustrations of two different $\mathrm{Ni} / \mathrm{Al}_{2} \mathrm{O}_{3}-\mathrm{YH}_{3}$ catalysts. A magnified TEM image of $\mathrm{Ni}(10 \mathrm{~nm}) / \mathrm{Al}_{2} \mathrm{O}_{3}$ is shown in the inset of (c); copyright (2019), J. Mater. Chem. A. 


\subsection{Dehydrogenation of Dodecahydro-N-Ethylcarbazoles}

Dodecahydro-N-ethylcarbazole has a mass hydrogen storage density of $5.8 \mathrm{wt} \%$, one molecule of which can remove six hydrogen molecules; the heat absorbed by the dehydrogenation reaction is $300^{\circ} \mathrm{C}$; and the reaction heat consumed accounts for $10.1 \%$ of the total stored hydrogen energy [111-114]. More importantly, the complete dehydrogenation of dodecahydro-N-ethylcarbazole can be achieved below $200{ }^{\circ} \mathrm{C}$, and the initial dehydrogenation temperature is even lower than $128^{\circ} \mathrm{C}$, which is the lowest organic liquid hydrogen storage compound found thus far. The dehydrogenation process of dodecahydro-N-ethylcarbazole, that is $12 \mathrm{H}-\mathrm{NECZ}$, is shown in Figure 4 [115]. First, 12H-NECZ removes hydrogen atoms from the four methylene groups in the middle to form $8 \mathrm{H}-\mathrm{NECZ}$. It then detaches two methylene hydrogen atoms from one side of the carbon ring to form a $4 \mathrm{H}-\mathrm{NECZ}$ or to form $6 \mathrm{H}-\mathrm{NECZ}$, and then taken off the two hydrogen atoms. Finally, the obtained material removes the four hydrogen atoms from the other side of the carbon ring to form N-ethylcarbazole.

At the beginning of the development of organic liquid hydrogen storage technology, the most commonly used catalyst was Pt due to its better dehydrogenability, but it is difficult to use widely in practical production due to its high price $[116,117]$. Therefore, researchers began to focus on the development and application of cheap metal catalysts, in which Ni has better dehydrogenation performance, which was given attention to in [118]. However, the Ni catalyst has fatal disadvantages: first, its dehydrogenation temperature is too high, usually above $30{ }^{\circ} \mathrm{C}$ [65]; and second, its adsorption on carbon atoms is very strong, which makes it prone to isomerization structure, resulting in poor selectivity of the dehydrogenation reaction [119]. Hence, in recent years, the most widely studied dehydrogenation catalyst has been the Pd metal catalyst because of its high dehydrogenation activity, low temperature, and low price relative to Pt. At present, for the dehydrogenation of dodecahydro-N-ethylcarbazole, the most commonly used and highly selective catalyst is a noble metal catalyst containing $\mathrm{Pd}$, usually added a second component to become a $\mathrm{Pd}-\mathrm{M}$ composite catalyst $[120,121]$. The catalyst activity depends to a large extent on the presence of a suitable atomic space group in the crystal lattice of the active component in order to aggregate the reactant molecules and product molecules.

Numerous experiments have been conducted to study the dehydrogenation of N-ethylcarbazole. Sotoodeh et al. [12] used $\mathrm{Pd} / \mathrm{SiO}_{2}$ to study the dehydrogenation of fully hydrogenated N-ethylcarbazole, and found that under $443 \mathrm{~K}$ and $101 \mathrm{KPa}$, the reaction conversion rate could reach $100 \%$ in $1.6 \mathrm{~h}$. Under the same conditions, the dehydrogenation efficiency of hydrogenated carbazole will be much lower. This is because the $\mathrm{N}$ atom of carbazole, its dehydrogenation product, is easily adsorbed on the surface of the Pd catalyst, which prevents the further progress of the reaction. Moreover, research shows that the dehydrogenation rate and selectivity of dodecahydro-N-ethylcarbazole depend on the size of the active component of Pd particles. Under the conditions of $443 \mathrm{~K}$ and $101 \mathrm{KPa}$, the particle size of the Pd particles was $9 \mathrm{~nm}$, and the catalytic activity was $4 \mathrm{wt} \%$ [122] and the dehydrogenation efficiency reached the highest. The adsorption of N-ethylcarbazole on the Pd surface contains many sites, and the adsorption of energy is related to the surface structure of Pd nanoparticles. At the same time, Jenssop et al. [96] developed a homogeneous Ir complex catalyst for the dehydrogenation of 1,2-ethylcarbazole. However, at $200{ }^{\circ} \mathrm{C}$, there was no selectivity for ethylcarbazole, only octadecyl carbazole and tetrahydroethyl carbazole. Other than that, Fang Tao et al. [123] reported a facile synthesis of $\mathrm{Pd}$ nanoparticles enclosed by $\{100\},\{110\}$, and $\{111\}$ facets supported on a reduced graphene oxide. Forberg et al. [124] found that bimetallic $\mathrm{Pd}-\mathrm{Ru}$ played a signification role in the hydrogenation of NECZ and the dehydrogenation of $12 \mathrm{H}-\mathrm{NECZ}$. 


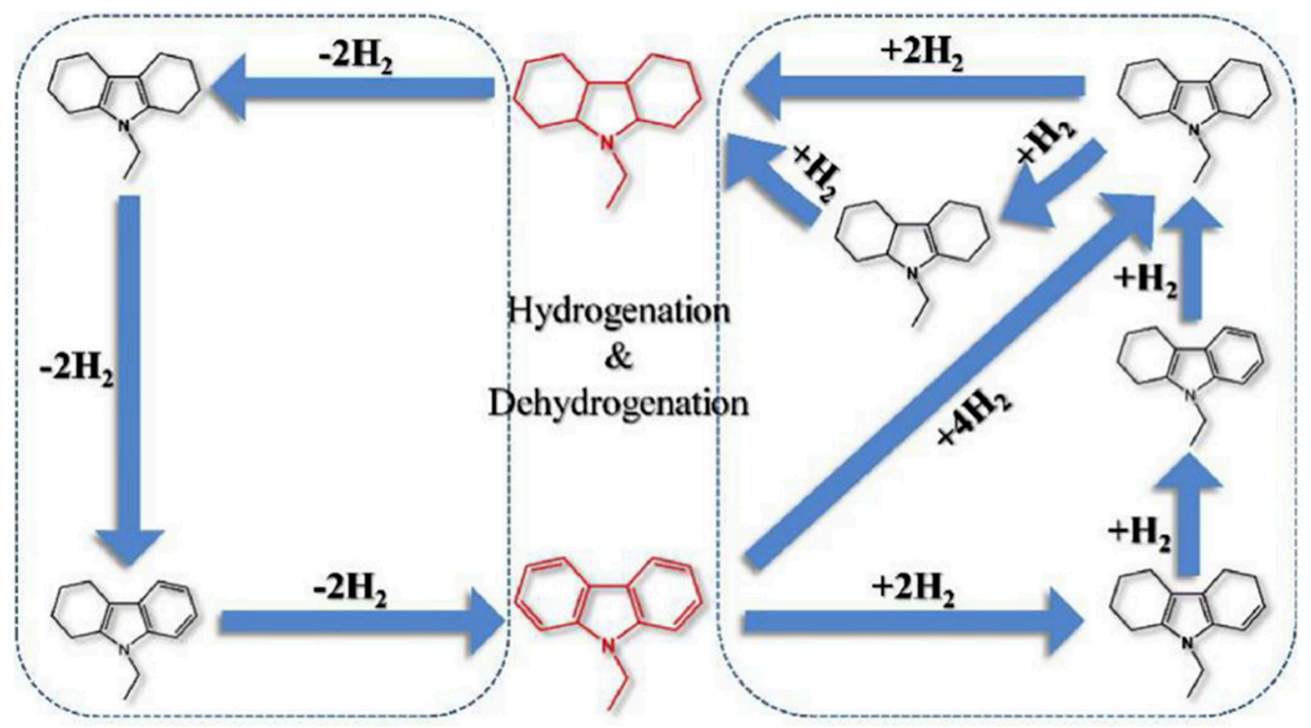

Figure 4. Hydrogenation (right) and dehydrogenation (left) pathways between NECZ and 12H-NECZ; copyright (2020), Elsevier.

In 2017, dehydrogenation of a 12-ethylcarbazole (12H-NECZ) reduced graphene oxide supported $\mathrm{Pd}$ catalyst prepared from ethylene glycol was reported by Wang et al. [125]. The specific activity of the $\mathrm{Pd} / \mathrm{rGO}_{\text {-EG }}$ catalyst was significantly increased up to 14.4 times, and the amount of noble metals used was only half that of the most advanced commercial $\mathrm{Pd} / \mathrm{Al}_{2} \mathrm{O}_{3}$ dehydrogenation catalyst. As shown in Figure 5, at 433, 443, and $453 \mathrm{~K}, 5.27,5.49$, and $5.78 \mathrm{wt} \%$ dehydrogenation can be obtained by using a $2.5 \mathrm{wt} \% \mathrm{Pd} / \mathrm{rGO}_{-\mathrm{EG}}$ catalyst, respectively. Introducing graphene into the design of dehydrogenation catalysts, particularly using its high theoretical surface area, good adsorption property, strong mechanical strength, excellent stability and conductivity, the special planar two-dimensional electronic structure not only facilitates the modification of various molecules and atoms, but also enhances the chemical properties of graphene. In addition, there are many active groups and defects on the surface of redox graphene, which can be used as active sites for adsorbing and anchoring metal nanoparticles.

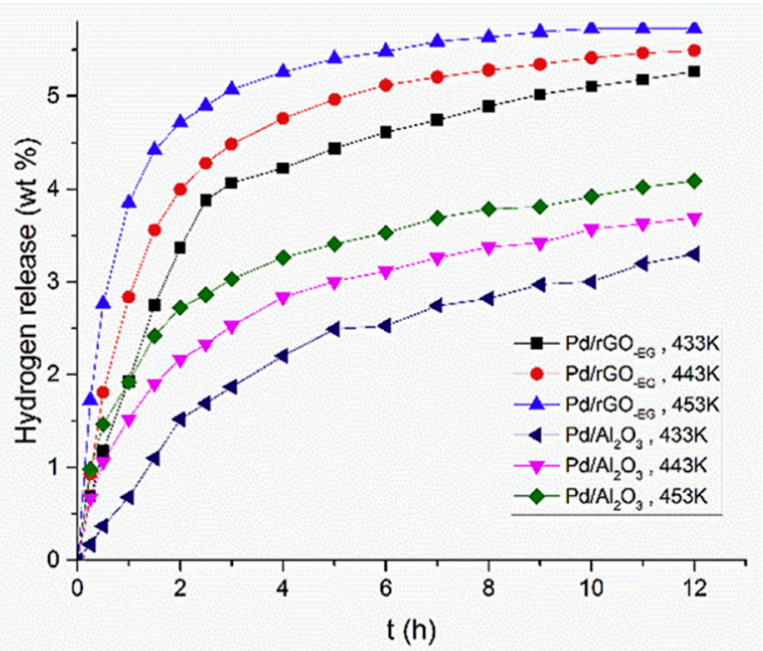

Figure 5. Plots of hydrogen content with time under different temperatures $(433,443$, and 453$)$ and under different supports $\left(\mathrm{Al}_{2} \mathrm{O}_{3}\right.$ and $\left.\mathrm{rGO}_{\text {-EG }}\right)$; copyright (2017), Elsevier.

A simple core-shell structure of Au-Pd-rGO was developed by Wang Bin et al. [126] in 2018. It was found that bimetallic catalysts were superior to single metal catalysts for $12 \mathrm{H}-\mathrm{NECZ}$ dehydrogenation, 
especially $\mathrm{Au}_{1} \mathrm{Pd}_{1.3} / \mathrm{rGO}$, with $100 \%$ selectivity and conversion. It can be seen from Figure 6 that the dehydrogenation activity of bimetallic catalysts with different molar ratios follows the order of $\mathrm{Au}_{1} \mathrm{Pd}_{1.3}$ $>\mathrm{Ru}_{1} \mathrm{Pd}_{1.3}>\mathrm{Rh}_{1} \mathrm{Pd}_{1.3}>\mathrm{Ag}_{1} \mathrm{Pd}_{1.3}$, with $\mathrm{Au}_{1} \mathrm{Pd}_{1.3} / \mathrm{rGO}$ having the highest dehydrogenation activity. In addition, the influence of the surface electronic properties of noble metal core/shell nanostructures on the catalytic activity has been studied. The results showed that charge transfer between atoms is otopy change, covering difference, $\mathrm{d}$-center shift, and the influence of the surface electronic structure caused by the different core/shell structure on the different reactions.

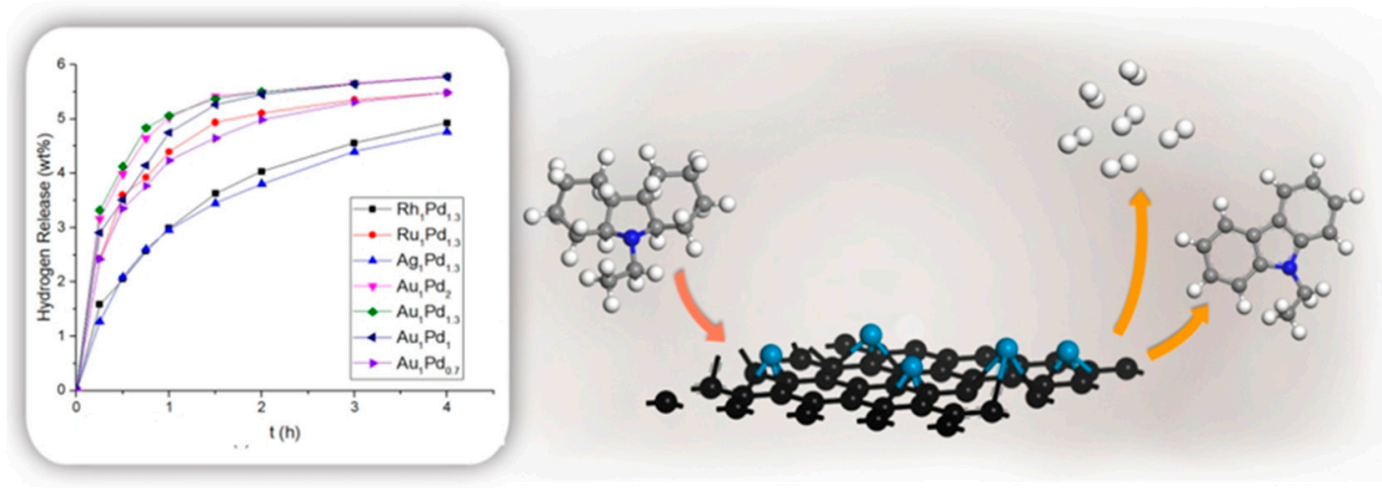

Figure 6. Hydrogen release amount for $12 \mathrm{H}-\mathrm{NEC}$ on different catalysts over time at $453 \mathrm{~K}$; copyright (2018), ACS Sustainable Chemistry \& Engineering.

In 2020, Wang et al. [123] studied the mechanism of the influence of crystal face on the performance of the catalyst, calculated the adsorption energy of reactant $12 \mathrm{H}-\mathrm{NEC}$, intermediate $8 \mathrm{H}-\mathrm{NEC}$, and $4 \mathrm{H}-\mathrm{NEC}$ and their products NEC on the surface of $\mathrm{Pd}\{111\},\{110\}$, and $\{100\}$, and optimized the configuration. For the $12 \mathrm{H}-\mathrm{NEC}$, it preferred the hollow positions adsorbed on the $\mathrm{Pd}\{111\},\{110\}$, and $\{100\}$ surfaces. As can be seen from Figure 7, after optimization, it was found that $8 \mathrm{H}-\mathrm{NEC}$ also preferred the hollow positions adsorbed on the $\mathrm{Pd}\{111\},\{110\}$, and $\{100\}$ surfaces. For $4 \mathrm{H}-\mathrm{NEC}$, the hollow adsorption configurations on the $\operatorname{Pd}\{111\},\{110\}$, and $\{100\}$ surfaces were ideal, in which the six-membered ring occupied the hollow position. The plane of the six-membered ring is parallel to the three Pd surfaces. On Pd $\{111\},\{110\}$, and $\{100\}$, the surface dependent properties of dehydrogenation from $12 \mathrm{H}-\mathrm{NEC}$ to NEC were significantly confirmed by Gibbs free energy, and Pd $\{100\}$ showed the best activity in the dehydrogenation reaction from $12 \mathrm{H}-\mathrm{NEC}$ to NEC.

a

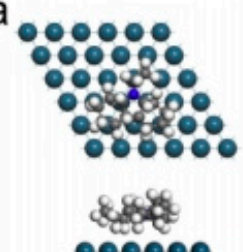

$12 \mathrm{H}-\mathrm{NEC}-\mathrm{Pd}\{111\}$

C

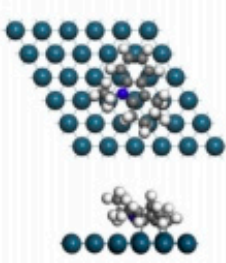

4H-NEC-Pd $\{111\}$
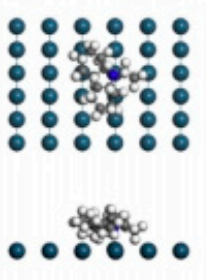

$12 \mathrm{H}-\mathrm{NEC}-\mathrm{Pd}\{110\}$
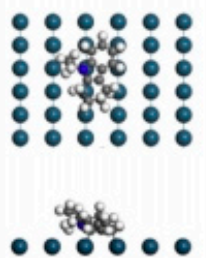

4H-NEC-Pd $\{110\}$
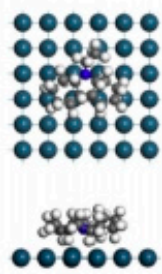

12H-NEC-Pd $\{100\}$
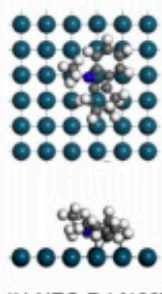

b
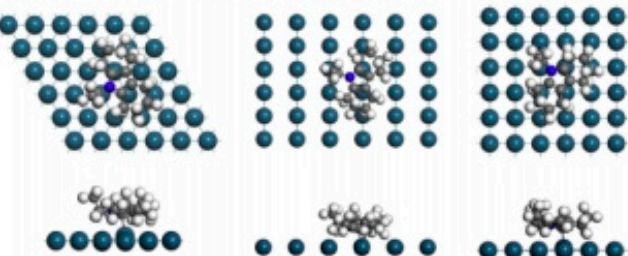

8 H-NEC-Pd $\{111\}$

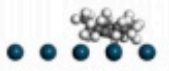

8 H-NEC-Pd $\{110\}$

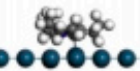

8 H-NEC-Pd $\{100\}$
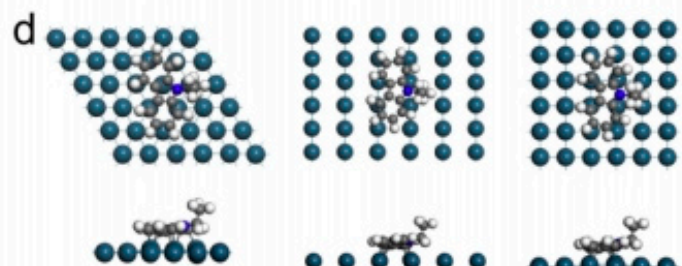

NEC-Pd \{111\}

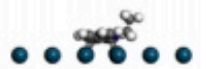

NEC-Pd $\{110\}$

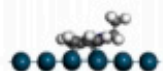

NEC-Pd $\{100\}$

Figure 7. Top and side views of the optimized adsorption configurations of (a) 12H-NEC, (b) 8H-NEC, (c) $4 \mathrm{H}-\mathrm{NEC}$, and (d) NEC on Pd $\{111\},\{110\}$, and $\{100\}$ surfaces. 
In 2019, Zhao Jiang et al. [127] proposed controlling the particle size and dispersion to improve the catalytic activity and selectivity of $\mathrm{PdAu} / \mathrm{SiO}_{2}$ for $12 \mathrm{H}-\mathrm{NECZ}$ dehydrogenation. Single metal catalysts $\mathrm{M} / \mathrm{SiO}_{2}$ and $\mathrm{PdAu} / \mathrm{SiO}_{2}$ with disparate ratios were prepared by the impregnation method. The activity, selectivity, and kinetics of these catalysts for 12H-NECZ dehydrogenation are shown in Figure 8.

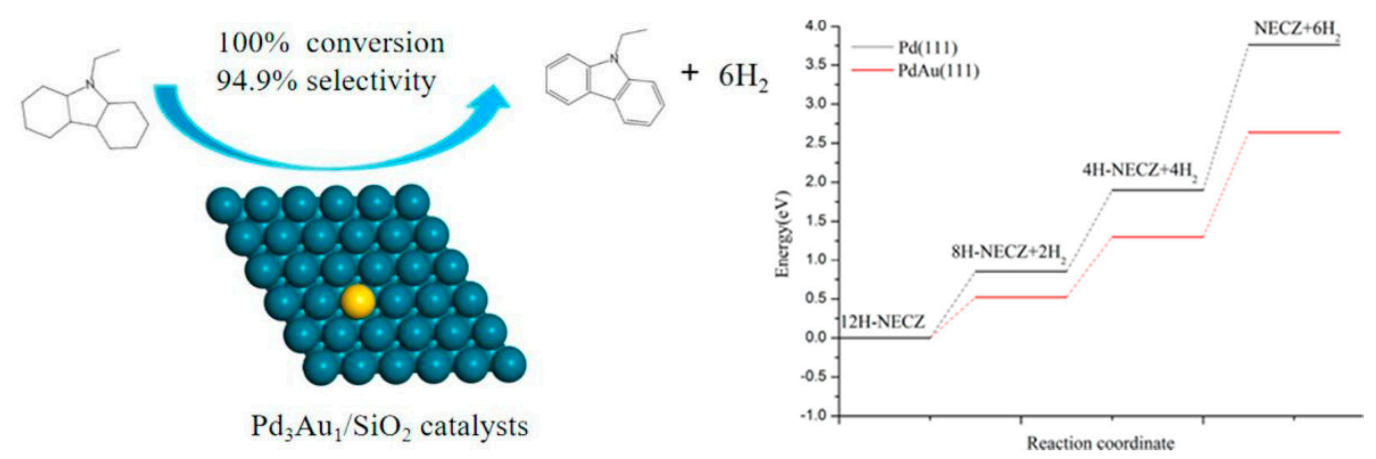

Figure 8. DFT-calculated energy profile of 12H-NECZ dehydrogenation to N-ethylcarbazole (NECZ) on the Pd (111) and PdAu (111) surfaces; copyright (2019), ACS Appl. Energy Mater.

\subsection{Summary}

NECZ hydrogenation is an exothermic reaction with an exothermic capacity of 50 to $53 \mathrm{~kJ} \mathrm{~mol}^{-1}$. On the supported Ru catalyst, the activation energy of NECZ hydrogenation was $99 \mathrm{~kJ} \mathrm{~mol}^{-1}$, which had the best catalytic selectivity and activity for $5 \mathrm{wt} \% \mathrm{Ru} / \mathrm{Al}_{2} \mathrm{O}_{3}$, and the catalytic selectivity for the complete hydrogenation isomer was $98 \%$. The activity order of the hydrogenation catalyst is $\mathrm{Ru}>\mathrm{Pd}$ $>\mathrm{Pt}>\mathrm{Ni}[28,128-130] .12 \mathrm{H}-\mathrm{NECZ}$ is an endothermic reaction with an endothermic capacity of 50 to $53 \mathrm{~kJ} \mathrm{~mol}^{-1}$. The activity sequence of the dehydrogenation catalyst is $\mathrm{Pd}>\mathrm{Pt}>\mathrm{Ru}>\mathrm{Rh}$ [131]. If using single metal catalysts that cannot meet all the requirements, $\mathrm{Pd}-\mathrm{Ni}$ and $\mathrm{Ru}-\mathrm{Ni}$ bimetallic composite catalysts can be used, which can reduce the amount of precious metals. Moreover, the addition of the second metal can change the activity and selectivity of the catalyst, and in particular, can improve the stability of the catalyst [132].

\section{Direction of Development}

Hydrogen storage by organic liquid hydrides is a promising technology $[133,134]$. Nowadays, the bottleneck of this technology is how to develop dehydrogenation catalysts with high conversion, high selectivity, and stability [135]. At the same time, the reaction is a highly endothermic heterogeneous reaction restricted by equilibrium, so it is important to choose the appropriate reaction mode and optimize the reaction conditions to solve the heat and mass transfer problems [128]. Furthermore, it is vital to solve the economic problems of the whole course of hydrogen storage such as how to reduce the quantity of noble metals in the catalyst and how to increase the energy efficiency of on-board dehydrogenation [136].

Since the use of a single metal catalyst cannot meet all the requirements, researchers can consider the use of bimetallic composite catalysts such as $\mathrm{Pd}-\mathrm{Ni}$ and $\mathrm{Ru}-\mathrm{Ni}$, can not only reduce the amount of precious metals used, but at the same time, the addition of the second metal may change the activity and selectivity of the catalyst, and can particularly improve the stability of the catalyst $[137,138]$. Super-critical fluid has high solubility and diffusivity, and has advantages that cannot be matched by ordinary liquid or gas phase reactions. It has been used primarily in hydrogenation reactions, because the ethyl carbazole is a solid at room temperature, and a suitable super-critical $\mathrm{CO}_{2}$ fluid can be added as a solvent to form a homogeneous reaction phase, which can improve the catalytic activity and reaction rate to a certain extent. In common dehydrogenation catalysts, noble metal components play the role of dehydrogenation, and acidic support is an important cause of coke and coke deposition. Therefore, the key to developing a dehydrogenation catalyst is to strengthen the 
dehydrogenation active center, while weakening the surface acidic center of the catalyst [139]. Another idea of developing the ethylcarbazole dehydrogenation catalyst is to modify the surface of the catalyst before loading the active component on the carrier, so as to improve the dispersion of the active component and the anti-coking performance of the catalyst [140]. At the same time, $\mathrm{Pd}$ and its alloy membrane have some selective permeability to hydrogen, so a membrane reactor can be used in the dehydrogenation process. Considering that the dehydrogenation of cycloalkanes is a reversible reaction limited by equilibrium, some researchers have considered using membrane reactors to change the mass transfer conditions to promote the equilibrium shift. Membrane reaction technology coupling chemical reaction with membrane separation technology, through timely separation of the reaction products, can effectively promote the reaction. Membrane reactors are usually used to increase the selectivity or yield of the process. Several membrane reactors commonly used for catalytic dehydrogenation include non-porous palladium membrane, microporous ceramic membrane, microporous thermostable glass membrane vycor glass membrane, and other types of membranes. The palladium membrane has been studied for a long time. The results show that the palladium membrane has high selective permeability to hydrogen, high purity of hydrogen, but low permeability, easy aging, and deactivation, but the high price of palladium membranes limits its industrial application [141]. Microporous ceramic membranes and microporous heat-resistant glass membranes are relatively cheap and stable at high temperature, but have poor hydrogen permeability. Therefore, in order to improve the efficiency of membrane separation and reduce the cost of membrane manufacturing, many researchers have also chosen to use molecular sieve membranes, palladium-free metal membranes, or metal composite membranes containing small amounts of palladium. The main byproducts of dehydrogenation process are 4-hydroethyl carbazole and 8-hydroethyl carbazole. The dehydrogenation process of these two products can be studied mainly through experiment or simulation; if a suitable catalyst can be found for dehydrogenation, the dehydrogenation of dodecylethylcarbazole may be solved fundamentally [142].

In a word, organic liquid hydrides have attracted the attention of research on account of their high hydrogen storage content and convenient transportation. They are a kind of hydrogen storage materials with great potential for development, which means that the severe energy problem will be alleviated to a certain extent.

\section{Conclusions}

Energy storage, especially hydrogen storage, has always been a concern and urgent problem of researchers and scientists. In this review, we compared different methods and materials of hydrogen storage, mainly for the hydrogenation catalyst and dehydrogenation catalyst of N-ethylcarbazole. At the present time, the bottleneck of N-ethylcarbazole dehydrogenation technology is how to develop a catalyst with higher conversion, better selectivity, and stability. In addition, hydrogen economy is another important factor to consider. It is an important direction to use nickel or other non-precious metals and Pd or Ru as bimetallic composite catalysts to reduce the use of precious metals. We hope that this review will provide further research efforts associated with N-ethylcarbazole as a promising hydrogen storage material.

Author Contributions: Conceptualization, Y.A. and C.W.; Writing—original draft preparation, L.Z., L.S., and M.Y.; Writing_-review and editing, M.Y., L.X., and Y.A.; Supervision, C.W. All authors have read and agreed to the published version of the manuscript.

Funding: This research was supported by Anhui Provincial Natural Science Foundation (1908085QB68), the Natural Science Foundation of the Anhui Higher Education Institutions of China (KJ2019A0072), the Major Science and Technology Project of Anhui Province (201903a05020055), the Foundation of Zhejiang Provincial Key Laboratory of Advanced Chemical Engineering Manufacture Technology (ZJKL-ACEMT-1802), the China Postdoctoral Science Foundation (2019M662060), and the Research Fund for Young Teachers of Anhui University of Technology (QZ201610).

Conflicts of Interest: The authors declare no conflicts of interest. 


\section{References}

1. Zou, H.; Guo, F.; Luo, M.; Yao, Q.; Lu, Z.H. La $(\mathrm{OH})_{3}$-decorated NiFe nanoparticles as efficient catalyst for hydrogen evolution from hydrous hydrazine and hydrazine borane. Int. J. Hydrog. Energy 2020, 45, 11641-11650. [CrossRef]

2. Zhang, L.T.; Ji, L.; Yao, Z.D.; Yan, N.H.; Sun, Z.X.; Yang, L.; Zhu, X.Q.; Hu, S.L.; Chen, L.X. Facile synthesized Fe nanosheets as superior active catalyst for hydrogen storage in $\mathrm{MgH}_{2}$. Int. J. Hydrog. Energy 2019, 44, 21955-21964. [CrossRef]

3. Yang, L.M.; Yi, G.P.; Hou, Y.N.; Cheng, H.Y.; Luo, X.B.; Pavlostathis, S.G.; Luo, S.L.; Wang, A.J. Building electrode with three-dimensional macroporous interface from biocompatible polypyrrole and conductive graphene nanosheets to achieve highly efficient microbial electrocatalysis. Biosens. Bioelectron. 2019, 141, 111444. [CrossRef] [PubMed]

4. Zhang, Y.K.; Xiong, Z.S.; Yang, L.M.; Ren, Z.; Shao, P.H.; Shi, H.; Xiao, X.; Pavlostathis, S.G.; Fang, L.L.; Luo, X.B. Successful isolation of a tolerant co-flocculating microalgae towards highly efficient nitrogen removal in harsh rare earth element tailings (REEs) wastewater. Water Res. 2019, 166, 115076. [CrossRef] [PubMed]

5. Wan, C.; Cheng, D.G.; Chen, F.Q.; Zhan, X.L. Fabrication of $\mathrm{CeO}_{2}$ nanotube supported Pt catalyst encapsulated with silica for high and stable performance. Chem. Commun. 2015, 51, 9785-9788. [CrossRef] [PubMed]

6. Sari, E.; Yilmaz, G.; Koyuncu, S.; Yagci, Y. Photoinduced Step-Growth Polymerization of N-Ethylcarbazole. J. Am. Chem. Soc. 2018, 140, 12728-12731. [CrossRef] [PubMed]

7. Muzzio, M.; Lin, H.; Wei, K.; Guo, X.; Yu, C.; Yom, T.; Sun, S. Efficient hydrogen generation from ammonia borane and tandem hydrogenation or hydrodehalogenation over AuPd nanoparticles. ACS Sustain. Chem. Eng. 2020, 8, 2814-2821. [CrossRef]

8. Liu, X.J.; Jiang, H.; Jia, Y.R.; Xia, M. Position-isomerization-induced switch effect of mechanofluorochromism and mechanoluminescence on carbazolylbenzo[d]imidazoles. Dye. Pigment. 2020, 172, 107845. [CrossRef]

9. Bingul, M.; Şenkuytu, E.; Saglam, M.F.; Boga, M.; Kandemir, H.; Sengul, I.F. Synthesis, photophysical and antioxidant properties of carbazole-based bis-thiosemicarbazones. Res. Chem. Intermed. 2020, 45, 4487-4499. [CrossRef]

10. Wang, B.; Chang, T.Y.; Jiang, Z.; Wei, J.J.; Fang, T. Component controlled synthesis of bimetallic PdCu nanoparticles supported on reduced graphene oxide for dehydrogenation of dodecahydro-N-ethylcarbazole. Appl. Catal. B-Environ. 2019, 251, 261-272. [CrossRef]

11. Chen, H.; Yang, Z.; Zhang, Z.; Chen, Z.; Chi, M.; Wang, S.; Fu, J.; Dai, S. Construction of a Nanoporous Highly Crystalline Hexagonal Boron Nitride from an Amorphous Precursor for Catalytic Dehydrogenation. Angew. Chem. Int. Ed. 2019, 58, 10626-10630. [CrossRef] [PubMed]

12. Niermann, M.; Beckendorff, A.; Kaltschmitt, M.; Bonhoff, K. Liquid Organic Hydrogen Carrier (LOHC)-Assessment based on chemical and economic properties. Int. J. Hydrog. Energy 2019, 44, 6631-6654. [CrossRef]

13. Jiang, Z.; Gong, X.; Wang, B.; Wu, Z.; Fang, T. An experimental study on the dehydrogenation performance of dodecahydro-N-ethylcarbazole on $\mathrm{M} / \mathrm{TiO}_{2}$ catalysts. Int. J. Hydrog. Energy 2019, 44, 2951-2959. [CrossRef]

14. Kaya, K.; Koyuncu, S.; Yagci, Y. Photoinduced synthesis of poly (N-ethylcarbazole) from phenacylium salt without conventional catalyst and/or monomer. Chem. Commun. 2019, 55, 11531-11534. [CrossRef] [PubMed]

15. Zheng, J.; Liu, X.; Xu, P.; Liu, P.; Zhao, Y.; Yang, J. Development of high pressure gaseous hydrogen storage technologies. Int. J. Hydrog. Energy 2012, 37, 1048-1057. [CrossRef]

16. Sadaghiani, M.S.; Mehrpooya, M. Introducing and energy analysis of a novel cryogenic hydrogen liquefaction process configuration. Int. J. Hydrog. Energy 2017, 42, 6033-6050. [CrossRef]

17. Zhao, X.; Ma, L. Recent progress in hydrogen storage alloys for nickel/metal hydride secondary batteries. Int. J. Hydrog. Energy 2009, 34, 4788-4796. [CrossRef]

18. Wu, Y.; Yu, H.; Guo, Y.; Jiang, X.; Qi, Y.; Sun, B.; Li, H.; Zheng, J.; Li, X. A rare earth hydride supported ruthenium catalyst for the hydrogenation of N-heterocycles: Boosting the activity via a new hydrogen transfer path and controlling the stereoselectivity. Chem. Sci. 2019, 10, 10459-10465. [CrossRef] [PubMed]

19. Wu, Y.; Yu, H.; Guo, Y.; Zhang, Y.; Jiang, X.; Sun, B.; Fu, K.; Chen, J.; Qi, Y.; Zheng, J.; et al. Promoting hydrogen absorption of liquid organic hydrogen carriers by solid metal hydrides. J. Mater. Chem. A 2019, 7, 16677-16684. [CrossRef] 
20. Hou, L.; Li, F.; Guo, J.; Zhang, X.; Kong, X.; Cui, X.T.; Dong, C.; Wang, Y.; Shuang, S. A colorimetric and ratiometric fluorescent probe for cyanide sensing in aqueous media and live cells. J. Mat. Chem. B 2019, 7, 4620-4629. [CrossRef] [PubMed]

21. Ren, X.; Liang, W.; Wang, P.; Bunker, C.E.; Coleman, M.; Teisl, L.R.; Cao, L.; Sun, Y.P. A new approach in functionalization of carbon nanoparticles for optoelectronically relevant carbon dots and beyond. Carbon 2019, 141, 553-560. [CrossRef]

22. Wan, C.; Zhou, L.; Sun, L.; Xu, L.X.; Cheng, D.G.; Chen, F.Q.; Zhan, X.L.; Yang, Y.R. Boosting visible-light-driven hydrogen evolution from formic acid over $\mathrm{AgPd} / 2 \mathrm{D} g-\mathrm{C}_{3} \mathrm{~N}_{4}$ nanosheets Mott-Schottky photocatalyst. Chem. Eng. J. 2020, 396, 125229. [CrossRef]

23. Itagaki, T.; Kurauchi, S.; Uebayashi, T.; Uji, H.; Kimura, S. Phase-separated molecular assembly of a nanotube composed of amphiphilic polypeptides having a helical hydrophobic block. ACS Omega 2018, 3, 7158-7164. [CrossRef] [PubMed]

24. Brückner, N.; Obesser, K.; Bösmann, A.; Teichmann, D.; Arlt, W.; Dungs, J.; Wasserscheid, P. Evaluation of Industrially applied heat-transfer fluids as liquid organic hydrogen carrier systems. ChemSusChem 2014, 7, 229-235. [CrossRef] [PubMed]

25. Wang, B.; Chang, T.Y.; Jiang, Z.; Wei, J.J.; Zhang, Y.H.; Yang, S.; Fang, T. Catalytic dehydrogenation study of dodecahydro-N-ethylcarbazole by noble metal supported on reduced graphene oxide. Int. J. Hydrog. Energy 2018, 43, 7317-7325. [CrossRef]

26. Zhang, F.; Wang, S.; Zhu, H.; Liu, X.; Liu, H.; Li, X.; Xiao, Y.; Zakeeruddin, S.M. Impact of peripheral groups on phenothiazine-based hole-transporting materials for perovskite solar cells. Acs. Energy. Lett. 2018, 3, 1145-1152. [CrossRef]

27. Wan, C.; Sun, L.; Xu, L.X.; Cheng, D.G.; Chen, F.Q.; Zhan, X.L.; Yang, Y.R. Novel NiPt alloy nanoparticle decorated 2D layered $\mathrm{g}-\mathrm{C}_{3} \mathrm{~N}_{4}$ nanosheets: A highly efficient catalyst for hydrogen generation from hydrous hydrazine. J. Mater. Chem. A 2019, 7, 8798-8804. [CrossRef]

28. Fei, S.; Han, B.; Li, L.; Mei, P.; Zhu, T.; Yang, M.; Cheng, H. A study on the catalytic hydrogenation of $\mathrm{N}$-ethylcarbazole on the mesoporous $\mathrm{Pd} / \mathrm{MoO}_{3}$ catalyst. Int. J. Hydrog. Energy 2017, 42, 25942-25950. [CrossRef]

29. Tang, R.R.; Zhang, W. Facile Procedure for the Synthesis of 3-Acetyl-9-ethylcarbazole and Corresponding Functionalized Bis- $\beta$-diketone Compounds. Synth. Commun. 2010, 40, 601-606. [CrossRef]

30. Bal, S.; Connolly, J.D. Synthesis, characterization, thermal and catalytic properties of a novel carbazole derived Azo ligand and its metal complexes. Arab. J. Chem. 2017, 10, 761-768. [CrossRef]

31. Chao, J.B.; Wang, H.J.; Zhang, Y.B.; Li, Z.Q.; Liu, Y.H.; Huo, F.J.; Yin, C.X.; Shi, Y.W.; Wang, J.J. A single pH fluorescent probe for biosensing and imaging of extreme acidity and extreme alkalinity. Anal. Chim. Acta 2017, 975, 52-60. [CrossRef] [PubMed]

32. Gawale, Y.; Adarsh, N.; Kalva, S.K.; Joseph, J.; Pramanik, M.; Ramaiah, D.; Sekar, N. Carbazole-linked near-infrared Aza-BODIPY dyes as triplet sensitizers and photoacoustic contrast agents for deep-tissue imaging. Chem. Eur. J. 2017, 23, 6570-6578. [CrossRef] [PubMed]

33. Mehranfar, A.; Izadyar, M. Theoretical evaluation of N-alkylcarbazoles potential in hydrogen release. Int. J. Hydrog. Energy 2017, 42, 9966-9977. [CrossRef]

34. Eçik, E.T.; Özcan, E.; Kandemir, H.; Sengul, I.F.; Çoşut, B. Light harvesting systems composed of carbazole based subphthalocyanine-BODIPY enhanced with intramolecular fluorescence resonance energy transfer (FRET). Dyes Pigment. 2017, 136, 441-449. [CrossRef]

35. Bal, S.; Köytepe, S.; Connolly, J.D. Synthesis of carbazole-derived ligands and their metal complexes: Characterization, thermal, catalytic, and electrochemical features. Mon. Chem. 2016, 147, 2061-2071. [CrossRef]

36. Choi, I.Y.; Shin, B.S.; Kwak, S.K.; Kang, K.S.; Yoon, C.W.; Kang, J.W. Thermodynamic efficiencies of hydrogen storage processes using carbazole-based compounds. Int. J. Hydrog. Energy 2016, 41, 9367-9373. [CrossRef]

37. Zhu, M.Y.; Xu, L.X.; Du, L.; An, Y.; Wan, C. Palladium supported on carbon nanotubes as a high-performance catalyst for the dehydrogenation of dodecahydro-N-ethylcarbazole. Catalysts 2018, 8, 638. [CrossRef]

38. Sultan, O.; Shaw, H. Study of automotive storage of hydrogen using recyclable liquid chemical carriers. Recon Tech. Rep. N 1975, 76, 33642.

39. Al-Auda, Z.; Al-Atabi, H.; Li, X.; Thapa, P.; Hohn, K. Conversion of 5-Methyl-3-Heptanone to C8 Alkenes and Alkane over Bifunctional Catalysts. Catalysts 2019, 9, 845. [CrossRef] 
40. Shen, Y.; Jiang, P.; Wai, P.T.; Gu, Q.; Zhang, W. Recent Progress in Application of Molybdenum-Based Catalysts for Epoxidation of Alkenes. Catalysts 2019, 9, 31. [CrossRef]

41. Baráth, E. Hydrogen Transfer Reactions of Carbonyls, Alkynes, and Alkenes with Noble Metals in the Presence of Alcohols/Ethers and Amines as Hydrogen Donors. Catalysts 2018, 8, 671. [CrossRef]

42. Tang, X.-T.; Yang, F.; Zhang, T.-T.; Liu, Y.-F.; Liu, S.-Y.; Su, T.-F.; Lv, D.-C.; Shen, W.-B. Recent Progress in $\mathrm{N}$-Heterocyclic Carbene Gold-Catalyzed Reactions of Alkynes Involving Oxidation/Amination/Cycloaddition. Catalysts 2020, 10, 350. [CrossRef]

43. Marcheggiani, E.; Tubaro, C.; Biffis, A.; Graiff, C.; Baron, M. Hydroalkoxylation of Terminal and Internal Alkynes Catalyzed by Dinuclear Gold(I) Complexes with Bridging Di(N-Heterocyclic Carbene) Ligands. Catalysts 2020, 10, 1. [CrossRef]

44. Francos, J.; Moreno-Narváez, M.E.; Cadierno, V.; Sierra, D.; Ariz, K.; Gómez, J. Gold(I) Complexes with Ferrocenylphosphino Sulfonate Ligands: Synthesis and Application in the Catalytic Addition of Carboxylic Acids to Internal Alkynes in Water. Catalysts 2019, 9, 955. [CrossRef]

45. Zhang, M.; Xiao, X.; Wu, Y.; An, Y.; Xu, L.; Wan, C. Hydrogen Production from Ammonia Borane over PtNi Alloy Nanoparticles Immobilized on Graphite Carbon Nitride. Catalysts 2019, 9, 1009. [CrossRef]

46. Charisteidis, I.; Lazaridis, P.; Fotopoulos, A.; Pachatouridou, E.; Matsakas, L.; Rova, U.; Christakopoulos, P.; Triantafyllidis, K. Catalytic Fast Pyrolysis of Lignin Isolated by Hybrid Organosolv-Steam Explosion Pretreatment of Hardwood and Softwood Biomass for the Production of Phenolics and Aromatics. Catalysts 2019, 9, 935. [CrossRef]

47. Yang, M.; Dong, Y.; Fei, S.X.; Pan, Q.Y.; Ni, G.; Han, C.Q.; Ke, H.Z.; Fang, Q.; Cheng, H.S. Hydrogenation of N-propylcarbazole over supported ruthenium as a new prototype of liquid organic hydrogen carriers (LOHC). RSC Adv. 2013, 3, 24877-24881. [CrossRef]

48. Peters, W.; Seidel, A.; Herzog, S.; Bösmann, A.; Schwieger, W.; Wasserscheid, P. Macrokinetic effects in perhydro-N-ethylcarbazole dehydrogenation and $\mathrm{H}_{2}$ productivity optimization by using egg-shell catalysts. Energy Environ. Sci. 2015, 8, 3013-3021. [CrossRef]

49. Stark, K.; Emel'yanenko, V.N.; Zhabina, A.A.; Varfolomeev, M.A.; Verevkin, S.P.; Muller, K.; Arlt, W. Liquid organic hydrogen carriers: Thermophysical and thermochemical studies of carbazole partly and fully hydrogenated derivatives. Ind. Eng. Chem. Res. 2015, 54, 7953-7966. [CrossRef]

50. Chao, J.; Liu, Y.; Sun, J.; Fan, L.; Zhang, Y.; Tong, H.; Li, Z. A ratiometric pH probe for intracellular $\mathrm{pH}$ imaging. Sens. Actuator B-Chem. 2015, 221, 427-433. [CrossRef]

51. Mehranfar, A.; Izadyar, M.; Esmaeili, A.A. Hydrogen storage by N-ethylcarbazol as a new liquid organic hydrogen carrier: A DFT study on the mechanism. Int. J. Hydrog. Energy 2015, 40, 5797-5806. [CrossRef]

52. Wang, F.; Wang, Z.; Wang, H.; Zhou, G. Synthesis and characterization of soluble poly (arylene ether ketones) with high glass transition temperature based on 3,6-bi (4-fluorobenzoyl)-N-alkylcarbazole. Polym. Int. 2015, 64, 258-266. [CrossRef]

53. Zhang, L.T.; Xiao, X.Z.; Chen, L.X.; Fan, X.L.; Zheng, J.G.; Huang, X. Correction for enhanced hydrogen storage properties of $\mathrm{MgH} 2$ with numerous hydrogen diffusion channels provided by $\mathrm{Na}_{2} \mathrm{Ti}_{3} \mathrm{O}_{7}$ nanotubes. J. Mater. Chem. A 2017, 5, 6178-6185. [CrossRef]

54. Zhang, L.T.; Sun, Z.; Cai, Z.L.; Yan, N.H.; Lu, X.; Zhu, X.Q.; Chen, L.X. Enhanced hydrogen storage properties of $\mathrm{MgH} 2$ by the synergetic catalysis of $\mathrm{Zr}_{0.4} \mathrm{Ti}_{0.6} \mathrm{Co}$ nanosheets and carbon nanotubes. Appl. Surf. Sci. 2020, $504,144465$.

55. Mehranfar, A.; Izadyar, M. N-Ethylcarbazole-doped fullerene as a potential candidate for hydrogen storage, a kinetics approach. RSC Adv. 2015, 5, 49159-49167. [CrossRef]

56. Peters, W.; Eypasch, M.; Frank, T.; Schwerdtfeger, J.; Körner, C.; Bösmann, A.; Wasserscheid, P. Efficient hydrogen release from perhydro-N-ethylcarbazole using catalyst-coated metallic structures produced by selective electron beam melting. Energ. Environ. Sci. 2015, 8, 641-649. [CrossRef]

57. Kono, T.; Shibata, Y.; Wang, Z.; Miyadera, T.; Yoshida, Y. Synthesis of Novel Push-Pull Chromophores based on N-Ethylcarbazole for Vacuum Deposition Processed Organic Photovoltaics. Chem. Lett. 2015, 44, 958-960. [CrossRef]

58. Sun, F.; An, Y.; Lei, L.; Wu, F.; Zhu, J.; Zhang, X. Identification of the starting reaction position in the hydrogenation of (N-ethyl) carbazole over Raney-Ni. J. Energy Chem. 2015, 24, 219-224. [CrossRef]

59. Papp, C.; Wasserscheid, P.; Libuda, J.; Steinrück, H.P. Liquid organic hydrogen carriers: Surface science studies of carbazole derivatives. Chem. Rec. 2014, 14, 879-896. [CrossRef] 
60. Wu, K.; Hu, Y.; Yang, W.; Zhang, T.; Guo, Q.; Yang, S.; Shi, Y. Solubility of N-Ethylcarbazole in different organic solvent at 279.15-319.15 K. Fluid Phase Equilib. 2014, 378, 78-82. [CrossRef]

61. Zhu, Q.; Gao, Y.J.; Gao, H.Y.; Jin, W.J. Effect of N-methyl and ethyl on phosphorescence of carbazole in cocrystals assembled by CI $\cdots \pi$ halogen bond, $\pi$-hole $\cdots \pi$ bond and other interactions using 1,4-diiodotetrafluorobenzene as donor. J. Photochem. Photobiol. A-Chem. 2014, 289, 31-38. [CrossRef]

62. Gleichweit, C.; Amende, M.; Bauer, U.; Schernich, S.; Höfert, O.; Lorenz, M.P.A.; Zhao, W.; Müller, M.; Koch, M.; Bachmann, P.; et al. Alkyl chain length-dependent surface reaction of dodecahydro-N-alkylcarbazoles on Pt model catalysts. J. Phys. Chem. Lett. 2014, 140, 204711. [CrossRef] [PubMed]

63. Amende, M.; Gleichweit, C.; Schernich, S.; Höfert, O.; Lorenz, M.P.A.; Zhao, W.; Koch, M.; Obesser, K.; Papp, C.; Wasserscheid, P.; et al. Size and structure effects controlling the stability of the liquid organic hydrogen carrier dodecahydro-N-ethylcarbazole during dehydrogenation over Pt model catalysts. J. Phys. Chem. Lett. 2014, 5, 1498-1504. [CrossRef] [PubMed]

64. Amende, M.; Gleichweit, C.; Werner, K.; Schernich, S.; Zhao, W.; Lorenz, M.P.A.; Höfert, O.; Papp, C.; Koch, M.; Wasserscheid, P.; et al. Model catalytic studies of liquid organic hydrogen carriers: Dehydrogenation and decomposition mechanisms of dodecahydro-N-ethylcarbazole on Pt (111). Acs Catal. 2014, 4, 657-665. [CrossRef] [PubMed]

65. Pez, G.P.; Scott, A.R.; Cooper, A.C.; Cheng, H.; Bagzis, L.; Appleby, J. Hydrogen storage reversible hydrogenated of pi-conjugated substrates. World Pat. 2005, 457, A2.

66. Niermann, M.; Drünert, S.; Kaltschmitta, M.; Bonhoff, K. Liquid organic hydrogen carriers (LOHCs) -techno-economic analysis of LOHCs in a defined process chain. Energy Environ. Sci. 2019, 12, 290. [CrossRef]

67. Wan, C.; An, Y.; Kong, W.; Xu, G. A study of catalytic dehydrogenation from dodecahydro-N-ethylcarbazole over a catalyst. Acta Energ. Sol. Sin. 2014, 35, 439-442.

68. Wan, C.; An, Y.; Kong, W.; Xu, G. Study of cyclic uptake-release of hydrogen with N-Ethylcarbazole. Acta Energ. Sol. Sin. 2014, 8, 38.

69. Jiang, Z.; Pan, Q.; Xu, J.; Fang, T. Current situation and prospect of hydrogen storage technology with new organic liquid. Int. J. Hydrog. Energy 2014, 39, 17442-17451. [CrossRef]

70. Wan, C.; An, Y.; Kong, W.; Xu, G. Study of hydrogenation of N-ethylcabazole over Ru/C catalyst. Acta Energ Sol. Sin. 2014, 2, 27.

71. Zhao, S.; Kang, J.; Du, Y.; Kang, J.; Zhao, X.; Xu, Y.; Chen, R.; Wang, Q.; Shi, X. An Efficient Ultrasound-Assisted Synthesis of N-Alkyl Derivatives of Carbazole, Indole, and Phenothiazine. J. Heterocycl. Chem. 2014, 51, 683-689. [CrossRef]

72. Asim, S.; Mansha, A.; Landgraf, S.; Grampp, G.; Zahid, M.; Bhatti, H.N. Spectral and thermodynamic properties for the exciplexes of $\mathrm{N}$-alkyl carbazoles with dicyanobenzenes in THF. Spectrochim. Acta Part A Mol. Biomol. Spectrosc. 2014, 118, 138-145. [CrossRef] [PubMed]

73. Li, L.; Wang, P.; Zhang, Y.; Wu, Y.; Chen, Z.; He, C. Synthesis, one and two-photon optical properties of two asymmetrical and symmetrical carbazole derivatives containing quinoline ring. J. Mol. Struct. 2013, 1051, 23-29. [CrossRef]

74. Sotoodeh, F.; Smith, K.J. An overview of the kinetics and catalysis of hydrogen storage on organic liquids. Can. J. Chem. Eng. 2013, 91, 1477-1490. [CrossRef]

75. Jiang, Z.; Xu, J.; Fang, T. Current situation and prospect for hydrogen storage technology with new organic liquid. Prog. Chem. 2012, 31, 315-322. [CrossRef]

76. Bader, N.; Ouederni, A. Optimization of biomass-based carbon materials for hydrogen storage. J. Energy Storage 2016, 5, 77-84. [CrossRef]

77. Li, Y.; Zhao, D.; Wang, Y.; Xue, R.; Shen, Z.; Li, X. The mechanism of hydrogen storage in carbon materials. Int. J. Hydrog. Energy 2017, 32, 2513-2517. [CrossRef]

78. Eberle, U.; Felderhoff, M.; Schueth, F. Chemical and physical solutions for hydrogen storage. Angew. Chem. Int. Ed. 2009, 48, 6608-6630. [CrossRef] [PubMed]

79. Züttel, A. Materials for hydrogen storage. Mater. Today 2003, 6, 24-33. [CrossRef]

80. Hao, L.L.; Li, J.F.; Lin, P.H.; Dong, R.F.; Shuang, S.M.; Dong, C. A novel carbazole-based fluorescent probe: 3 , 6-Bis-[(N-ethylcarbazole-3-yl)-propene-1-keto]-N-ethylcarbazole. Chin. Chem. Lett. 2010, 21,9-12. [CrossRef]

81. Aakko-Saksa, P.T.; Cook, C.; Kiviaho, J.; Repo, T. Liquid organic hydrogen carriers for transportation and storing of renewable energy-Review and discussion. J. Power Sources 2018, 396, 803-823. [CrossRef] 
82. Gleichweit, C.; Amende, M.; Schernich, S.; Zhao, W.; Lorenz, M.P.A.; Höfert, O.; Brückner, N.; Wasserscheid, P.; Libuda, J.; Steinrück, H.P.; et al. Dehydrogenation of Dodecahydro-N-ethylcarbazole on Pt (111). ChemSusChem 2013, 6, 974-977. [CrossRef] [PubMed]

83. Kinashi, K.; Wang, Y.; Nonomura, A.; Tsujimura, S.; Sakai, W.; Tsutsumi, N. Dynamic holographic images using poly (N-vinylcarbazole)-based photorefractive composites. Polym. J. 2013, 45, 665-670. [CrossRef]

84. Gao, S.; Hao, L.; Li, J.; Lin, P.; Li, D.; Shuang, S.; Dong, C. Photophysical processes of an intramolecular charge transfer fluorescent dye with carbazole units. Luminescence 2013, 28, 412-418. [CrossRef] [PubMed]

85. Giridhar, T.; Cho, W.; Park, J.; Park, J.S.; Gal, Y.S.; Kang, S.; Lee, J.Y.; Jin, S.H. Facile synthesis and characterization of iridium (III) complexes containing an N-ethylcarbazole-thiazole main ligand using a tandem reaction for solution processed phosphorescent organic light-emitting diodes. J. Phys. Chem. C 2013, 1, 2368-2378. [CrossRef]

86. Sotoodeh, F.; Smith, K.J. Analysis of $\mathrm{H}_{2}$ release from organic polycyclics over Pd catalysts using DFT. J. Phys. Chem. C 2013, 117, 194-204. [CrossRef]

87. Clot, E.; Eisenstein, O.; Crabtree, R.H. Computational structure-activity relationships in $\mathrm{H}_{2}$ storage: How placement of $\mathrm{N}$ atoms affects release temperatures in organic liquid storage materials. Chem. Commun. 2007, 22, 2231-2233. [CrossRef] [PubMed]

88. Zhu, Q.L.; Xu, Q. Liquid organic and inorganic chemical hydrides for high-capacity hydrogen storage. Energy Environ. Sci. 2015, 8, 478-512. [CrossRef]

89. Cacciola, G.; Giordano, N.; Restuccia, G. Cyclohexane as a liquid phase carrier in hydrogen storage and transport. Int. J. Hydrog. Energy 1984, 9, 411-419. [CrossRef]

90. Shukla, A.A.; Gosavi, P.V.; Pande, J.V.; Kumar, V.P.; Chary, K.V.; Biniwale, R.B. Efficient hydrogen supply through catalytic dehydrogenation of methylcyclohexane over Pt/metal oxide catalysts. Int. J. Hydrog. Energy 2010, 35, 4020-4026. [CrossRef]

91. Kariya, N.; Fukuoka, A.; Utagawa, T.; Sakuramoto, M.; Goto, Y.; Ichikawa, M. Efficient hydrogen production using cyclohexane and decalin by pulse-spray mode reactor with Pt catalysts. Appl. Catal. A Gen. 2003, 247, 247-259. [CrossRef]

92. Kustov, L.M.; Tarasov, A.L.; Tarasov, B.P. Intermetallide catalysts for hydrogen storage on the basis of reversible aromatics hydrogenation/dehydrogenation reactions. Int. J. Hydrog. Energy 2013, 38, 5713-5716. [CrossRef]

93. Sotoodeh, F.; Zhao, L.; Smith, K.J. Kinetics of $\mathrm{H}_{2}$ recovery from dodecahydro-N-ethylcarbazole over a supported Pd catalyst. Appl. Catal. A Gen. 2009, 362, 155-162. [CrossRef]

94. Copper, A.C.; Campbell, K.M.; Perez, G.P. An integrated hydrogen storage and delivery approach using organic liquid-phase carriers. In Proceedings of the 16th World Hydrogen Energy Conference, Lyon, France, 13-16 June 2006; pp. 2164-2175.

95. Moores, A.; Poyatos, M.; Luo, Y.; Crabtree, R.H. Catalysed low temperature $\mathrm{H}_{2}$ release from nitrogen heterocycles. New J. Chem. 2006, 30, 1675-1678. [CrossRef]

96. Cui, Y.; Kwok, S.; Bucholtz, A.; Davis, B.; Whitney, R.A.; Jessop, P.G. The effect of substitution on the utility of piperidines and octahydroindoles for reversible hydrogen storage. New J. Chem. 2008, 32, 1027-1037. [CrossRef]

97. Yamaguchi, R.; Ikeda, C.; Takahashi, Y.; Fujita, K.I. Homogeneous catalytic system for reversible dehydrogenation-hydrogenation reactions of nitrogen heterocycles with reversible interconversion of catalytic species. J. Am. Chem. Soc. 2009, 131, 8410-8412. [CrossRef] [PubMed]

98. Fujita, K.I.; Tanaka, Y.; Kobayashi, M.; Yamaguchi, R. Homogeneous perdehydrogenation and perhydrogenation of fused bicyclic N-heterocycles catalyzed by iridium complexes bearing a functional bipyridonate ligand. J. Am. Chem. Soc. 2014, 136, 4829-4832. [CrossRef] [PubMed]

99. Campbell, P.G.; Zakharov, L.N.; Grant, D.J.; Dixon, D.A.; Liu, S.Y. Hydrogen Storage by Boron-Nitrogen Heterocycles: A Simple Route for Spent Fuel Regeneration. J. Am. Chem. Soc. 2010, 132, 3289-3291. [CrossRef] [PubMed]

100. Luo, W.; Campbell, P.G.; Zakharov, L.N.; Liu, S.Y. A single-component liquid-phase hydrogen storage material. J. Am. Chem. Soc. 2011, 133, 19326-19329. [CrossRef] [PubMed]

101. Hodoshima, S.; Takaiwa, S.; Shono, A.; Satoh, K.; Saito, Y. Hydrogen storage by decalin/naphthalene pair and hydrogen supply to fuel cells by use of superheated liquid-film-type catalysis. Appl. Catal. A Gen. 2005, 283, 235-242. [CrossRef] 
102. Morawa Eblagon, K.; Tam, K.; Yu, K.K.; Zhao, S.L.; Gong, X.Q.; He, H.; Ye, L.; Wang, L.C.; Ramirez-Cuesta, A.J.; Tsang, S.C. Study of catalytic sites on ruthenium for hydrogenation of N-ethylcarbazole: Implications of hydrogen storage via reversible catalytic hydrogenation. J. Phys. Chem. C 2010, 114, 9720-9730. [CrossRef]

103. Eblagon, K.M.; Tam, K.; Tsang, S.C.E. Comparison of catalytic performance of supported ruthenium and rhodium for hydrogenation of 9-ethylcarbazole for hydrogen storage applications. Energy Environ. Sci. 2012, 5, 8621-8630. [CrossRef]

104. Kinashi, K.; Shinkai, H.; Sakai, W.; Tsutsumi, N. Photorefractive device using self-assembled monolayer coated indium-tin-oxide electrodes. Org. Electron. 2013, 14, 2987-2993. [CrossRef]

105. Verevkin, S.P.; Emel'yanenko, V.N.; Heintz, A.; Stark, K.; Arlt, W. Liquid Organic Hydrogen Carriers: An Upcoming Alternative to Conventional Technologies Thermochemical Studies. Ind. Eng. Chem. Res. 2012, 51, 12150-12153. [CrossRef]

106. Shi, H.-P.; Dai, J.-X.; Shi, L.-W.; Xu, L.; Zhou, Z.-B.; Zhang, Y.; Zhou, W.; Dong, C. Synthesis, photophysical and electrochemical properties of a carbazole dimer-based derivative with benzothiazole units. Spectrochim. Acta Part A Mol. Biomol. Spectrosc. 2012, 93, 19-25. [CrossRef] [PubMed]

107. Yang, M.; Dong, Y.; Fei, S.; Ke, H.; Cheng, H. A comparative study of catalytic dehydrogenation of perhydro-N-ethylcarbazole over noble metal catalysts. Int. J. Hydrog. Energy 2014, 39, 18976-18983. [CrossRef]

108. Wan, C.; An, Y.; Xu, G.; Kong, W. Study of catalytic hydrogenation of N-ethylcarbazole over ruthenium catalyst. Int. J. Hydrog. Energy 2012, 37, 13092-13096. [CrossRef]

109. Wan, C.; An, Y.; Chen, F.; Cheng, D.; Wu, F.; Xu, G. Kinetics of N-ethylcarbazole hydrogenation over a supported Ru catalyst for hydrogen storage. Int. J. Hydrog. Energy 2013, 38, 7065-7069. [CrossRef]

110. Yu, H.; Yang, X.; Wu, Y.; Guo, Y.; Li, S.; Lin, W.; Li, X.G.; Zheng, J. Bimetallic Ru-Ni/TiO 2 catalysts for hydrogenation of N-ethylcarbazole: Role of $\mathrm{TiO}_{2}$ crystal structure. J. Energy Chem. 2020, 40, 188-195. [CrossRef]

111. Erginer, M.; Sezer, E.; Ustamehmetoğlu, B.; Heinze, J. Voltammetric, electrochemical quartz crystal microbalance and in situ conductance studies of conducting polymers based on ethylenedioxythiophene and N-ethylcarbazole. Electrochim. Acta 2012, 67, 181-186. [CrossRef]

112. Sotoodeh, F.; Huber, B.J.; Smith, K.J. The effect of the $\mathrm{N}$ atom on the dehydrogenation of heterocycles used for hydrogen storage. Appl. Catal. A-Gen. 2012, 419, 67-72. [CrossRef]

113. Mosnáček, J.; Nicolaÿ, R.; Kar, K.K.; Fruchey, S.O.; Cloeter, M.D.; Harner, R.S.; Matyjaszewski, K. Efficient polymerization inhibition systems for acrylic acid distillation: New liquid-phase inhibitors. Ind. Eng. Chem. Res. 2012, 51, 3910-3915. [CrossRef]

114. Ahluwalia, R.K.; Hua, T.Q.; Peng, J.K. On-board and off-board performance of hydrogen storage options for light-duty vehicles. Int. J. Hydrog. Energy 2012, 37, 2891-2910. [CrossRef]

115. Gong, X.; Jiang, Z.; Fang, T. Enhancing selectivity and reducing cost for dehydrogenation of dodecahydro-N-ethylcarbazole by supporting platinum on titanium dioxide. Int. J. Hydrog. Energy 2020, 45, 6838-6847. [CrossRef]

116. Ghinet, A.; Van Hijfte, N.; Gautret, P.; Rigo, B.; Oulyadi, H.; Rousseau, J. Studies on pyrrolidinones. Reaction of pyroglutamic acid and vinylogues with aromatics in Eaton's reagent. Tetrahedron 2012, 68, 1109-1116. [CrossRef]

117. Zhao, L.; Qian, C.; Gong, L.; Chen, X.Z. Synthesis of 1-\{6-(2-methylbenzoyl)-N-ethylcarbazole-3-yl\}-ethane-1-one oxime O-acetate. Res. Chem. Intermed. 2012, 38, 105-111. [CrossRef]

118. Masuo, S.; Yamane, Y.; Machida, S.; Itaya, A. Fluorescence behavior of individual charge-transfer complexes revealed by single-molecule fluorescence spectroscopy: Influence of the host polymer matrix. J. Photochem. Photobiol. A-Chem. 2012, 227, 65-70. [CrossRef]

119. Zhang, J.; Cui, H.; Hojo, M.; Shuang, S.; Dong, C. Synthesis and spectral studies of 2- [(N-ethyl carbazole)-3-sulfonyl ethylenediamine]-1-N, N-2-(2-methypyridy) as a fluorescence probe for $\mathrm{Zn}^{2+}$. Bioorg. Med. Chem. Lett. 2012, 22, 343-346. [CrossRef] [PubMed]

120. Shan, L.; Xiaoyan, Y.; Xiaobo, C.; Jing, W.; Hongjun, Z. Synthesis methods for a series of acetyl aromatic compounds. Spec. Petrochem. 2011, 6, 6 .

121. Shi, H.P.; Xu, L.; Cheng, Y.; He, J.Y.; Dai, J.X.; Xing, L.W.; Chen, B.Q.; Fang, L. Experimental and theoretical study of three new benzothiazole-fused carbazole derivatives. Spectrochim. Acta Part A Mol. Biomol. Spectrosc. 2011, 81, 730-738. [CrossRef] [PubMed] 
122. Sotoodeh, F.; Huber, B.J.; Smith, K.J. Dehydrogenation kinetics and catalysis of organic heteroaromatics for hydrogen storage. Int. J. Hydrog. Energy 2012, 37, 2715-2722. [CrossRef]

123. Wang, B.; Chen, Y.T.; Chang, T.Y.; Jiang, Z.; Huang, Z.Q.; Wang, S.Y.; Chang, C.R.; Chen, Y.S.; Wei, J.J.; Yang, S.; et al. Facet-dependent catalytic activities of Pd/rGO: Exploring dehydrogenation mechanism of dodecahydro-N-ethylcarbazole. Appl. Catal. B-Environ. 2020, 266, 118658. [CrossRef]

124. Forberg, D.; Schwob, T.; Zaheer, M.; Friedrich, M.; Miyajima, N.; Kempe, R. Single-catalyst high-weight $\%$ hydrogen storage in an N-heterocycle synthesized from lignin hydrogenolysis products and ammonia. Nat. Commun. 2016, 7, 1-6. [CrossRef] [PubMed]

125. Wang, B.; Yan, T.; Jiang, Z.; Chang, T.Y.; Wei, J.J.; Zhou, Q.; Fang, T. Palladium supported on reduced graphene oxide as a high-performance catalyst for the dehydrogenation of dodecahydro-Nethylcarbazole. Carbon 2017, 122, 9-18. [CrossRef]

126. Wang, B.; Chang, T.Y.; Gong, X.; Jiang, Z.; Yang, S.; Chen, Y.S.; Fang, T. One-Pot Synthesis of Au/Pd Core/Shell Nanoparticles Supported on Reduced Graphene Oxide with Enhanced Dehydrogenation Performance for Dodecahydro-N-ethylcarbazole. ACS Sustain. Chem. Eng. 2019, 7, 1760-1768. [CrossRef]

127. Jiang, Z.; Guo, S.; Fang, T. Enhancing the catalytic activity and selectivity of $\mathrm{PdAu} / \mathrm{SiO}_{2}$ bimetallic catalysts for dodecahydro-N-ethylcarbazole dehydrogenation by controlling the particle size and dispersion. ACS Appl. Energy Mater. 2019, 2, 7233-7243. [CrossRef]

128. Eblagon, K.M.; Rentsch, D.; Friedrichs, O.; Remhof, A.; Zuettel, A.; Ramirez-Cuesta, A.J.; Tsang, S.C. Hydrogenation of 9-ethylcarbazole as a prototype of a liquid hydrogen carrier. Int. J. Hydrog. Energy 2010, 35, 11609-11621. [CrossRef]

129. Amende, M.; Schernich, S.; Sobota, M.; Nikiforidis, I.; Hieringer, W.; Assenbaum, D.; Görling, A. Dehydrogenation mechanism of liquid organic hydrogen carriers: Dodecahydro-N-ethylcarbazole on Pd (111). Chem.-Eur. J. 2013, 19, 10854-10865. [CrossRef] [PubMed]

130. Ye, X.; An, Y.; Xu, G. Kinetics of 9-ethylcarbazole hydrogenation over Raney-Ni catalyst for hydrogen storage. J. Alloys Compd. 2010, 509, 152-156. [CrossRef]

131. Sobota, M.; Nikiforidis, I.; Amende, M.; Zanón, B.S.; Staudt, T.; Höfert, O.; Lykhach, Y.; Papp, C.; Hieringer, W.; Laurin, M.; et al. Dehydrogenation of Dodecahydro-N-ethylcarbazole on $\mathrm{Pd} / \mathrm{Al}_{2} \mathrm{O}_{3}$ Model Catalysts. Chem.-Eur. J. 2011, 17, 11542-11552. [CrossRef]

132. Liu, X.; Sun, Y.; Zhang, Y.; Miao, F.; Wang, G.; Zhao, H.; Yu, X.; Liu, H.; Wong, W.Y. A2, 7-carbazole-based dicationic salt for fluorescence detection of nucleic acids and two-photon fluorescence imaging of RNA in nucleoli and cytoplasm. Org. Biomol. Chem. 2011, 9, 3615-3618. [CrossRef] [PubMed]

133. Sotoodeh, F.; Smith, K.J. Structure sensitivity of dodecahydro-N-ethylcarbazole dehydrogenation over Pd catalysts. J. Catal. 2010, 279, 36-47. [CrossRef]

134. Ates, M. A comparative study of redox parameters and electrochemical impedance spectroscopy of polycarbazole derivatives on carbon fiber microelectrode. Fiber. Polym. 2010, 11, 1094-1100. [CrossRef]

135. Geng, W.Q.; Li, X.L.; Yin, J.H.; Zhou, H.P.; Wu, J.Y.; Tian, Y.P. Synthesis, crystal structure and photoluminescence of a new Cd (II) coordination polymer with unusual geometry. Inorg. Chem. Commun. 2010, 13, 1285-1288. [CrossRef]

136. Kustov, L.M.; Tarasov, A.L.; Kirichenko, O.A. Microwave-activated dehydrogenation of perhydro-N-ethylcarbazol over bimetallic $\mathrm{Pd}-\mathrm{M} / \mathrm{TiO}_{2}$ catalysts as the second stage of hydrogen storage in liquid substrates. Int. J. Hydrog. Energy 2017, 42, 26723-26729. [CrossRef]

137. Gong, L.; Qian, C.; Chen, X. Synthesis of 3-acetyl-6-(o-methyl benzoyl)-N-ethylcarbazole. Res. Chem. Intermed. 2010, 36, 383-387. [CrossRef]

138. Cui, Y.; Chen, Q.; Zhang, D.D.; Cao, J.; Han, B.H. Triphenylamine-based fluorescent conjugated copolymers with pendant terpyridyl ligands as chemosensors for metal ions. J. Polym. Sci. Pol. Chem. 2010, 48, 1310-1316. [CrossRef]

139. Park, M.J.; Kwak, J.; Lee, J.; Jung, I.H.; Kong, H.; Lee, C.; Hwang, D.H.; Shim, H.K. Single chain white-light-emitting polyfluorene copolymers containing iridium complex coordinated on the main chain. Macromolecules 2010, 43, 1379-1386. [CrossRef]

140. Sotoodeh, F.; Smith, K.J. Kinetics of hydrogen uptake and release from heteroaromatic compounds for hydrogen storage. Ind. Eng. Chem. Res. 2010, 49, 1018-1026. [CrossRef] 
141. Shi, H.P.; Cheng, Y.; Jing, W.J.; Chao, J.B.; Fang, L.; Dong, X.; Dong, C. Experimental and theoretical study of a new carbazole derivative having terminal benzimidazole rings. Spectrochim. Acta Part A Mol. Biomol. Spectrosc. 2010, 75, 525-532. [CrossRef] [PubMed]

142. Lu, Z.H.; Xu, Q. Recent progress in boron-and nitrogen-based chemical hydrogen storage. Funct. Mater. Lett. 2012, 5, 1230001. [CrossRef]

(C) 2020 by the authors. Licensee MDPI, Basel, Switzerland. This article is an open access article distributed under the terms and conditions of the Creative Commons Attribution (CC BY) license (http://creativecommons.org/licenses/by/4.0/). 